\title{
Application of the Principle of Portability for Participants of National Health Insurance outside the Domicile Area in Gaining Access to Health Services in the City of Semarang
}

(Penerapan Prinsip Portabilitas Bagi Peserta Jaminan Kesehatan Nasional di Luar Wilayah Domisili dalam Memperoleh Akses Pelayanan Kesehatan di Kota Semarang)

\section{Marni Dominika Oenunu; Yohanes Budi Sarwo; Daniel B. Wibowo; Endang Wahyati Yustina} email: marnioenunu@yahoo.co.id

\author{
Master of Health Law, Soegijapranata Catholic University Semarang
}

\begin{abstract}
The portability principles in the National Health Insurance Program (JKN) implementation are principles that guarantee JKN participants whenever and wherever they are as far as in the Indonesian area. This includes any participant who moves his/her job or residence, has a vacation, does a study or does other business. This happens in all areas in Indonesia, including in Semarang City. The philosophical base for the implementation of the portability principle is the right to access health services. When suffering sick a JKN participant should receive his or her health insurance rights by possibly accessing health services at the nearest degree of First Level Health Facility. However, the fact was that remained facing obstacles. The purpose of this study was to obtain an overview of the form regulations, the factors influencing the implementation of portability principles for out-domiciled JKN participants in getting access to health services at Semarang City.

This study used a socio-legal approach having a descriptive-analytical specification. The primary data of this study were obtained through interviews with the Health Social Security Organizing Agency (BPJS) of Semarang Branch and five health centre's heads, namely Pandanaran, Sekaran, Ngesrep, Srondol, and Kedungmundu health centres beside 25 out-domiciled JKN participants of Semarang as informants. The sampling technique used purposive sampling with qualitative analysis.

The implementation of the portability principles for out-domiciled JKN participants in getting access to health services at Semarang City, especially in the 5 health centres does not go well. The form regulations of the implementation portability principles based on a circular letter issued by Health BPJS Office of Semarang Branch number 766 / VI-01/0518 on Out-Domiciled Participant Services of FKTP is maximum visit limit 3 times which is contrary to the portability principles in Article 4 of Act No. 40 of 2004 on National Social Security System and Act No. 24 of 2011 on the Social Security Organizing Agency. Need for technical regulations in the form of a binding Minister Decree concerning requirements, administrative procedures, and service procedures for the implementation of portability principles. Juridical factors influencing were there are no technical regulations on the implementation of the portability principles for out-domiciled JKN participants in getting access to health services including the utilization of the JKN Mobile application. Social factors and technical factors had no adequate information and understanding to implement the portability principles.
\end{abstract}

Keywords: principles portability, JKN, domicile, services.

Abstrak: Prinsip portabilitas dalam penyelenggaraan Program Jaminan Kesehatan Nasional (JKN) merupakan prinsip menjamin peserta JKN kapan dan dimanapun di Indonesia termasuk saat berpindah pekerjaan atau tempat tinggal, liburan, kuliah atau urusan lainnya tak terkecuali di Kota Semarang. Landasan filosofis penerapan prinsip portabilitas adalah hak akses pelayanan kesehatan. Peserta JKN ketika sakit seharusnya memperoleh hak akses pelayanan kesehatan di Fasilitas Kesehatan Tingkat Pertama (FKTP) terdekat, namun faktanya masih ditemui kendala. Tujuan penelitian adalah untuk mendapatkan gambaran bentuk pengaturan, faktor-faktor yang 
mempengaruhi dan penerapan prinsip portabilitas bagi peserta JKN di luar wilayah domisili dalam memperoleh akses pelayanan kesehatan di Kota Semarang.

Metode penelitian yang digunakan adalah pendekatan yuridis sosiologis dengan spesifikasi penelitian deskriptif analitis. Data primer diperoleh melalui wawancara dengan Badan Penyelenggaraan Jaminan Sosial (BPJS) Kesehatan Kantor Cabang Semarang dan lima Kepala Puskesmas: Pandanaran, Sekaran, Ngesrep, Srondol, dan Kedungmundu sebagai narasumber serta 25 responden peserta JKN luar wilayah domisili Kota Semarang. Metode sampling menggunakan purposive sampling dengan analisis kualitatif.

Penerapan prinsip portabilitas bagi peserta JKN di luar wilayah domisili dalam memperoleh akses pelayanan kesehatan di Kota Semarang terutama di kelima Puskesmas yang diteliti belum optimal. Bentuk pengaturan penerapan prinsip portabilitas didasarkan Surat Edaran BPJS Kesehatan Kantor Cabang Semarang Nomor 766/VI-01/0518 tentang Pelayanan Peserta Peserta Luar Wilayah di FKTP yaitu batasan maksimal kunjungan 3 kali yang bertentangan dengan prinsip portabilitas dalam Pasal 4 huruf $f$ Undang-Undang Nomor 40 Tahun 2004 tentang SJSN dan Undang-Undang Nomor 24 Tahun 2011 tentang BPJS. Perlu peraturan teknis berupa Keputusan Menteri yang mengikat tentang persyaratan, prosedur administratif, dan prosedur layanan penerapan prinsip portabiltas tersebut. Faktor yuridis yang mempengaruhi yaitu belum ada peraturan teknis tentang penerapan prinsip portabilitas bagi peserta JKN di luar wilayah domisili dalam memperoleh akses pelayanan kesehatan termasuk pemanfaatan aplikasi Mobile JKN. Faktor sosial dan faktor teknis juga masih kurang informasi dan pemahaman dalam penerapannya.

Kata kunci: prinsip portabilitas, JKN, domisili, pelayanan.

\section{PENDAHULUAN}

Kesehatan merupakan hak dasar atau hak fundamental warga negara dalam kehidupan berbangsa dan bernegara. Hal ini sebagaimana tertuang dalam Undang-Undang Dasar Negara Republik Indonesia Tahun 1945 Pasal 28H ayat (1) bahwa "setiap orang berhak memperoleh pelayanan kesehatan", dan Pasal 34 ayat (2) bahwa "negara mengembangkan sistem jaminan sosial bagi seluruh rakyat"'. Pemerintah dalam upaya memberikan jaminan kesehatan sosial secara menyeluruh dimulai dengan mengeluarkan Undang-Undang Nomor 40 Tahun 2004 tentang Sistem Jaminan Sosial Nasional yang selanjutnya disebut UndangUndang SJSN. Hal tersebut dipertegas dalam Pasal 19 ayat (1) Undang-Undang SJSN yang secara eksplisit menyebutkan bahwa "jaminan kesehatan diselenggarakan secara nasional berdasarkan prinsip asuransi sosial dan prinsip ekuitas" 2 .

Berdasarkan kedua prinsip di atas, diharapkan permasalahan pembiayaan kesehatan dan mutu pelayanan kesehatan di Indonesia dapat teratasi dengan penyelenggaraan program jaminan sosial kesehatan. Salah satu keuntungan program jaminan kesehatan sosial yang kemudian dikenal dengan Jaminan Kesehatan Nasional adalah memiliki portabilitas ${ }^{3}$. Prinsip portabilitas adalah prinsip memberikan jaminan sosial yang berkelanjutan meskipun peserta berpindah pekerjaan atau tempat tinggal dalam wilayah Negara Kesatuan Republik

\footnotetext{
${ }^{1}$ Yohanes Budi Sarwo, 2012, Sistem Jaminan Sosial Kesehatan yang Berkeadilan dalam Negara Kesejahteraan di Indonesia, Semarang: Universitas Katolik Soegijapranata, hal. iii.

2 Undang-Undang Nomor 40 Tahun 2004 tentang Sistem Jaminan Sosial Nasional diakses dari http://peraturan.go.id/common/dokumen/In/2004/uu40-2004.pdf tanggal 01 November 2017.

3 Kementerian Kesehatan Republik Indonesia, 2014, Buku Pegangan Sosialisasi Jaminan Kesehatan Nasional (JKN) Dalam Sistem Jaminan Sosial Nasional, Jakarta: Kemenkes RI, hal. 14.
} 
Indonesia4. Prinsip tersebut secara eksplisit terdapat dalam Pasal 4 Undang-Undang SJSN, yaitu Sistem Jaminan Sosial Nasional diselenggarakan berdasarkan pada prinsip:

a. kegotong-royongan;

b. nirlaba;

c. keterbukaan;

d. kehati-hatian;

e. akuntabilitas;

f. portabilitas;

g. kepesertaan bersifat wajib;

h. dana amanat; dan

i. hasil pengelolaan Dana Jaminan Sosial dipergunakan seluruhnya untuk pengembangan program dan sebesar-besar kepentingan peserta5.

Selanjutnya dalam Pasal 4 Undang-Undang Nomor 24 Tahun 2011 tentang Badan Penyelenggara Jaminan Sosial yang selanjutnya disebut Undang-Undang BPJS, kembali menegaskan bahwa BPJS termasuk didalamnya BPJS Kesehatan dalam menyelenggarakan Jaminan Kesehatan Nasional tetap mengacu pada prinsip-prinsip Sistem Jaminan Sosial Nasional di atas tak terkecuali prinsip portabilitas.

Jaminan Kesehatan Nasional atau yang selanjutnya disebut JKN merupakan program jaminan sosial yang menjamin biaya pemeliharaan kesehatan serta pemenuhan kebutuhan dasar kesehatan yang diselenggarakan nasional secara bergotong-royong wajib oleh seluruh penduduk Indonesia dengan membayar iuran berkala atau iurannya dibayari oleh Pemerintah kepada badan penyelenggara jaminan sosial nirlaba atau BPJS Kesehatan ${ }^{6}$.

Peserta Jaminan Kesehatan Nasional di Indonesia setelah 4 tahun terlaksananya Program Jaminan Kesehatan Nasional terhitung 1 Mei 2018 berjumlah 196.662.064 jiwa dan total 27.140 Fasilitas Kesehatan Jaminan Kesehatan Nasonal diantaranya 22.069 Fasilitas Kesehatan Tingkat Pertama dan 5.071 Fasilitas Kesehatan Rujukan Tingkat Lanjutan?. Sedangkan sesuai data BPJS Kesehatan Kantor Cabang Kota Semarang jumlah Peserta Jaminan Kesehatan Nasional Kota Semarang sampai 30 September 2017 adalah sebanyak 1.472.500 jiwa dari jumlah total penduduk Kota Semarang 1.648.279 jiwa atau 95\% penduduk Kota Semarang sudah terdaftar sebagai Peserta Jaminan Kesehatan Nasional ${ }^{8}$.

Prinsip portabilitas yang dimaksudkan dalam penyelenggaraan JKN oleh BPJS Kesehatan adalah peserta JKN selalu terjamin atau terlindungi kapan dan dimanapun berada di dalam yurisdiksi Indonesia. Jaminan tersebut diberikan secara berkelanjutan sampai peserta meninggal dunia. Selain itu, peserta yang berpindah pekerjaan atau berpindah tempat tinggal dalam wilayah Negara Kesatuan Republik Indonesia juga harus selalu terlindungi ${ }^{9}$. Sehingga

\footnotetext{
4 Penjelasan Pasal 4 huruf f Undang-Undang Nomor 24 Tahun 2011 tentang Badan Penyelenggara Jaminan Sosial diakses dari http://bpjs-kesehatan.go.id/bpjs/index.php/unduh/index/1 pada tanggal 01 November 2017.

5 Undang-Undang Nomor 40 Tahun 2004 tentang Sistem Jaminan Sosial Nasional diakses dari http://peraturan.go.id/inc/view/11e44C4f10857720aef7313231383339.html tanggal 01 November 2017.

${ }^{6}$ Asih Eka Putri, 2014, Paham JKN Jaminan Kesehatan Nasional, Jakarta: Friedrich-Elbert Stiftung, hal. 9.

7 Anonim, "Peserta Program JKN dan Fasilitas Kesehatan JKN", BPJS Kesehatan, Jakarta, diakses dari https://bpjskesehatan.go.id/bpjs/index.php/home. 4 April 2018.

8 Humas BPJS Kesehatan, “Kota Semarang Menuju Universal Health Coverage”, BPJS Kesehatan, Jakarta, diakses dari https://bpjs-kesehatan.go.id/bpjs/index.php/post/read/2017/580/Kota-Semarang-Menuju-UniversalHealth-Coverage. 4 April 2018.

9 Hasbullah Thabrany, 2015, Jaminan Kesehatan Nasional, Edisi kedua, Jakarta: PT RajaGrafindo Persada, hal. 173.
} 
SOEPRA Jurnal Hukum Kesehatan

TERAKREDITASI RISTEKDIKTI Peringkat 4

ISSN:2548-818X (media online) Vol. 7 (1) Juni 2021

peserta JKN tidak dibatasi jaminannya dalam suatu wilayah tertentu dalam mengakses manfaat JKN.

Kebijakan BPJS Kesehatan dalam menerapkan prinsip portabilitas bagi peserta Jaminan Kesehatan Nasional di luar wilayah domisili dalam memperoleh akses pelayanan kesehatan adalah sebagai berikut: bagi peserta yang tengah bepergian tidak rutin melaporkan ke kantor cabang BPJS Kesehatan agar diketahui posisinya dan diverifikasi kepesertaanya, bagi peserta yang bepergian rutin misalnya pekerja di luar kota juga harus melaporkan ke Kantor BPJS Kesehatan agar mendapatkan solusi, dan bagi peserta yang sementara waktu domisili di luar tempat tinggal melapor ke BPJS Kesehatan agar dipindahkan sementara waktu ke tempat domisili dengan data pendukung berupa Surat Keterangan Pemangku Wilayah tentang domisili tersebut ${ }^{10}$.

Kebijakan di atas tentu saja sangat membantu para peserta BPJS Kesehatan untuk memperoleh akses pelayanan kesehatan. Namun realita menunjukkan bahwa penerapan kebijakan tersebut tidak segampang dibayangkan. Seorang peserta Jaminan Kesehatan Nasional dalam Surat Pembaca mengeluhkan prosedur BPJS Kesehatan terkait perpindahan fasilitas kesehatan hanya bisa dilakukan dalam waktu minimal 3 bulan dinilai rumit. Bagaimana tidak ia berpendapat bahwa Jaminan Kesehatan tersebut harusnya bisa digunakan dimana saja di seluruh Indonesia tanpa harus melalui prosedur yg rumit ${ }^{11}$. Warga Desa Karangmojo, Kecamatan Karangmojo, Kabupaten Gunung Kidul, Daerah Istimewa Yogyakarta juga mengeluhkan kesulitan perpindahan fasilitas kesehatan karena banyakya persyaratan dari BPJS Kesehatan dan kepengurusan berkas yang dilakukan tidak boleh bersama-sama ${ }^{12}$.

Dalam rangka meningkatkan layanan dan memudahkan peserta Jaminan Kesehatan Nasional untuk mengakses pelayanan kesehatan tanggal 15 November 2017, Direktur Utama BPJS Kesehatan, Fahmi Idris meluncurkan aplikasi Mobile JKN. Dengan mengunduh aplikasi ini, peserta JKN bisa lebih efisien waktu dan biaya ${ }^{13}$. Keuntungan lain yang diperoleh dari aplikasi Mobile JKN adalah peserta JKN dapat dengan mudah melakukan perpindahan Fasilitas Kesehatan Tingkat Pertama yang selanjutnya disebut FKTP termasuk di luar wilayah domisili tetapi dibatasi minimal 3 bulan sekali.

Kota Semarang sebagai salah satu kota metropolitan dan sekaligus ibu kota Propinsi Jawa Tengah juga memiliki berbagai fasilitas yang sangat memadai sehingga Kota Semarang siap menjadi magnet yang kuat untuk menarik para pendatang berdomisili. Akan tetapi, permasalahan muncul ketika mereka mulai mengalami sakit. Faktanya setiap peserta JKN dalam keadaan normal hanya dapat memperoleh pelayanan kesehatan di satu FKTP pilihan peserta ketika mendaftar sebagai peserta JKN di wilayah kependudukan atau domisili. Sedangkan peserta JKN sendiri tidak pernah bisa memilih harus selalu sakit di wilayah kependudukan atau domisilinya. Akibatnya ketika peserta JKN sakit di luar wilayah

10 Anonim, "Kartu JKN-KIS Laku di Setiap Wilayah", dalam “Info BPJS Kesehatan, Edisi 47 Tahun 2017, hal. 13, diakses dari https://bpjs-kesehatan.go.id/bpjs/dmdocuments/bbc24a1f1e75dc915ca1ff55b9cc5199.pdf. 04 April 2018.

${ }^{11}$ Anonim, “Peraturan BPJS yang rumit", Kompas, 9 Maret 2017, diakses dari https://kompas.id/baca/opini/2017/03/og/surat-kepada-redaksi-83/.11 April 2018.

${ }^{12}$ Anonim, "Warga Keluhkan Sulitnya Perpindahan Fasilitas Kesesehatan dari BPJS Kesehatan", Okezone, Yogyakarta: 18 Februari 2018, diakses dari https://economy.okezone.com/read/2018/02/18/320/1861036/wargakeluhkan-sulitnya-perpindahan-fasilitas-kesehatan-dari-bpjs-kesehatan. 11 April 2018.

13 Anonim, "Layanan Ditawarkan dalam Sistem Digital", Kompas, Jakarta: 16 November 2017, diakses dari https://kompas.id/baca/humaniora/ilmu-pengetahuan-teknologi/2017/11/16/layanan-ditawarkan-dalam-sistemdigital/. 11 April 2018. 
SOEPRA Jurnal Hukum Kesehatan

TERAKREDITASI RISTEKDIKTI Peringkat 4

ISSN:2548-818X (media online) Vol. 7 (1) Juni 2021

domisilinya, peserta JKN tidak dapat memperoleh akses pelayanan kesehatan sebagai peserta JKN namun harus membayar biaya pelayanan kesehatan sebagai pasien umum.

Padahal sesungguhnya sebagai peserta JKN yang diselenggarakan berdasarkan prinsip portabilitas, peserta JKN harusnya dapat memperoleh akses pelayanan kesehatan sebagai peserta JKN. Akses pelayanan kesehatan yang dimaksud adalah pelayanan kesehatan harus dapat dicapai dan tidak terhalang oleh keadaan geografis ${ }^{14}$ bagi peserta JKN dimanapun berada selama masih dalam Wilayah Kesatuan Republik Indonesia termasuk Kota Semarang. Meskipun saat ini peserta JKN sudah mendapatkan kemudahan dengan aplikasi Mobile JKN, peserta JKN tidak dapat sesegera mungkin memindahkan FKTP karena dibatasi waktu minimal 3 bulan.

Hasil studi pendahuluan yang dilakukan pada BPJS Kesehatan Cabang Kota Semarang diperoleh bahwa jumlah peserta Jaminan Kesehatan Nasional di Kota Semarang terhitung 1 Mei 2018 meningkat drastis dengan cakupan 100\% penduduk Kota Semarang yaitu sebanyak 2.418.548 jiwa. Selain itu, jumlah total Fasilitas Kesehatan yang sudah menjadi partner BPJS Kesehatan Cabang Kota Semarang sebanyak 265, diantaranya 241 FKTP dan 24 FKRTL. FKTP yang dimaksud antara lain 37 puskesmas, 97 klinik, 72 praktik dokter dan 35 praktik dokter gigi. Sedangkan FKRTL meliputi 5 rumah sakit pemerintah dan 19 rumah sakit swasta.

Semua Fasilitas Kesehatan di atas yang sudah menjadi partner BPJS Kesehatan Kantor Cabang Semarang sudah tercover 100\% dengan aplikasi Mobile JKN sehingga memudahkan akses pelayanan kesehatan bagi peserta Jaminan Kesehatan Nasional termasuk didalamnya peserta Jaminan Kesehatan Nasional di luar wilayah domisili Kota Semarang. Adapun kebijakan BPJS Kesehatan Kantor Cabang Semarang untuk peserta Jaminan Kesehatan Nasional di luar wilayah domisili Kota Semarang dapat mengakses pelayanan kesehatan di FKTP dengan cara datang langsung ke FKTP lalu menunjukkan kartu Jaminan Kesehatan Nasional atau Jaminan Kesehatan Nasional digital melalui Aplikasi Mobile JKN. Namun, pelayanan kesehatan tersebut hanya dapat diperoleh sebanyak 3 kali saja.

Sementara lama domisili di Kota Semarang bagi masing-masing peserta beragam. Bagi yang studi lama domisili dapat berkisar tiga sampai lima tahun, sedangkan bagi yang bekerja kurun waktu domisili lebih dari setengah tahun. Bila dibandingkan batasan 3 kali kunjungan dengan lama domisili peserta maka sangat mungkin kebutuhan pelayanan kesehatan peserta melebihi dari batasan tersebut. Akibatnya, ketika melebihi 3 kali kunjungan maka peserta membayar sebagai pasien umum meskipun peserta sudah disarankan untuk pindah FKTP. Pindah FKTP bagi peserta sangat rumit karena peserta harus mengurus pindah FKTP ke BPJS Kesehatan Kantor Cabang Semarang yang juga memakan waktu. Selain itu, peserta juga dalam kesempatan tertentu kembali ke daerah asalnya untuk sekedar berlibur atau mengunjungi keluarganya. Apakah peserta harus mengurus pindah FKTP lagi? Ditambah lagi, peserta belum pernah mendengar informasi tentang Aplikasi Mobile JKN dan kegunaannya.

\section{RUMUSAN MASALAH}

Berdasarkan uraian latar belakang diatas maka dapat dirumuskan perumusan masalah sebagai berikut:

\footnotetext{
14 Imbalo S. Pohan, 2003, Jaminan Mutu Pelayanan Kesehatan-Dasar-Dasar Pengertian, Jakarta: Kesaint Blanc, hal 20.
} 
1. Bagaimana bentuk pengaturan tentang penerapan prinsip portabilitas bagi peserta Jaminan Kesehatan Nasional di luar wilayah domisili dalam memperoleh akses pelayanan kesehatan di Kota Semarang?

2. Bagaimana penerapan prinsip portabilitas bagi peserta Jaminan Kesehatan Nasional di luar wilayah domisili dalam memperoleh akses pelayanan kesehatan di Kota Semarang?

3. Faktor-faktor apa saja yang mempengaruhi penerapan prinsip portabilitas bagi peserta Jaminan Kesehatan Nasional di luar wilayah domisili dalam memperoleh akses pelayanan kesehatan di Kota Semarang?

\section{METODE PENELITIAN}

1. Metode Pendekatan

Metode pendekatan yang digunakan dalam penelitian ini adalah pendekatan yuridis sosiologis, yang merupakan pendekatan berbasis pada ilmu hukum normatif (peraturan perundangan), tetapi bukan mengkaji sistem norma dalam aturan perundangan, namun mengamati reaksi dan interaksi yang terjadi ketika sistem norma itu bekerja di dalam masyarakat ${ }^{15}$. Pendekatan ini merupakan pendekatan yang digunakan untuk melihat aspek-aspek hukum dalam interaksi sosial di dalam masyarakat ${ }^{16}$.

Melalui pendekatan ini dapat dibahas dua aspek sekaligus terkait dengan aspek yuridis, yaitu Bentuk Peraturan Hukum Penerapan Prinsip Portabilitas bagi Peserta Jaminan Kesehatan Nasional di Luar Wilayah Domisili dalam Memperoleh Akses Pelayanan Kesehatan dan aspek sosial yang melingkupi, Penerapan dari Bentuk Peraturan tersebut di Kota Semarang.

2. Spesifikasi Penelitian

Penelitian ini menggunakan spesifikasi penelitian deskriptif analitis, yang menganalisis peraturan perundang-undangan yang berkaitan dengan teori-teori hukum sebagai objek penelitiannya dan pelaksanaan hukum dalam masyarakat ${ }^{17}$. Dalam penelitian ini, peneliti menggambarkan Penerapan Prinsip Portabilitas bagi Peserta Jaminan Kesehatan Nasional di Luar Wilayah Domisili dalam Memperoleh Akses Pelayanan Kesehatan di Kota Semarang serta faktor-faktor yang mempengaruhinya secara rinci, sistematis, dan menyeluruh, kemudian dianalisa secara konsisten, dan logis berdasarkan peraturanperaturan terkait dan teori-teori.

Selain itu, peneliti ingin mengetahui Penerapan Prinsip Portabilitas bagi Peserta Jaminan Kesehatan Nasional di Luar Wilayah Domisili dalam Memperoleh Akses Pelayanan Kesehatan di Kota Semarang yang dilaksanakan oleh BPJS Kesehatan Kota Semarang sebagai Badan Penyelenggara Jaminan Sosial Kesehatan, Fasilitas Kesehatan Tingkat Pertama di Kota Semarang terutama Puskesmas sebagai fasilitas penyelenggara pelayanan kesehatan dan Peserta Jaminan Kesehatan Nasional di Luar Wilayah Domisili Kota Semarang sebagai sasaran objek penelitian.

\footnotetext{
15 Mukti Fajar Nur Dewata dan Yulianto Achmad, 2010, Dualisme Penelitian Hukum Normatif \& Empiris, Yogyakarta: Pustaka Pelajar, hal. 47.

${ }^{16}$ Zainuddin Ali, 2015, Metode Penelitian Hukum, Jakarta: Sinar Grafika, hal. 105.

17 Ibid, hal. 105-106.
} 


\section{Jenis Data}

Jenis data di dalam penelitian berdasarkan sumbernya, dibedakan antara data yang diperoleh langsung dari masyarakat yang disebut data primer atau data dasar (primary data atau basic data) dan dari tinjauan pustaka atau teori yang disebut data sekunder (secondary data). Data primer diperoleh langsung dari sumber pertama berupa fakta perilaku warga masyarakat saat peneliti melakukan penelitian. Sedangkan data sekunder mencakup dokumen-dokumen resmi, buku-buku, hasil-hasil penelitian, buku harian, dan lain sebagainya ${ }^{18}$.

Data primer dalam penelitian ini diperoleh dengan pengambilan data melalui hasil wawancara pada narasumber, sedangkan data sekunder diperoleh melalui dokumendokumen dan data dari BPJS Kota Semarang mengenai Penerapan Prinsip Portabilitas bagi Peserta Jaminan Kesehatan Nasional di Luar Wilayah Domisili dalam Memperoleh Akses Pelayanan Kesehatan di Kota Semarang.

4. Metode Pengumpulan Data

Metode pengumpulan data dalam penelitian ini dilakukan dengan dua metode yaitu studi lapangan dan studi kepustakaan.

\section{a. Studi Lapangan}

Sebagai penelitian yuridis sosiologis, penelitian ini bertitik tolak pada data primer. Data primer adalah data yang didapat langsung dari sumber pertama melalui studi lapangan ${ }^{19}$. Adapun teknik studi lapangan antara lain dengan observasi, wawancara, penyebaran kuesioner, survey, atau focus group discussion (FGD ${ }^{20}$.

Dalam penelitian ini, peneliti melakukan studi lapangan pada lokasi penelitian yang telah ditentukan yakni BPJS Kesehatan Cabang Semarang, Puskesmas di wilayah Kota Semarang, dan Peserta Jaminan Kesehatan Nasional di Luar Wilayah Domisili Kota Semarang. Sedangkan cara pengumpulan data studi lapangan dalam penelitian ini dilakukan dengan wawancara.

b. Studi Kepustakaan

Studi kepustakaan merpakan metode pengumpulan data yang digunakan dalam penelitian yuridis sosiologis (hukum empiris) selain menggunakan metode pengumpulan data yang lain ${ }^{21}$. Studi kepustakaan dalam penelitian ini berupa data sekunder yang diperoleh melalui: bahan hukum primer, bahan hukum sekunder, dan bahan hukum tersier.

\section{Metode Sampling}

Metode sampling yang digunakan dalam penelitian ini adalah metode non-probability sampling yaitu purposive sampling. Purposive sampling atau penarikan sampel dilakukan sendiri oleh peneliti dengan berdasarkan pertimbangan bahwa responden yang dipilih dapat mewakili populasi ${ }^{22}$. Teknik pengumpulan data dalam penelitian ini hanya menggunakan metode wawancara kepada narasumber dan responden dengan jenis pertanyaan terbuka. Wawancara dilakukan dengan menggunakan pedoman wawancara

\footnotetext{
18 Soerjono Soekanto, 1986, Pengantar Penelitian Hukum, Cetakan 3, Jakarta: Penerbit Universitas Indonesia (UIPress), hal. 11-12.

19 Bambang Waluyo, 1996, Penelitian Hukum dalam Praktek, Jakarta: Sinar Grafika, hal. 16.

${ }^{20}$ Agnes Widanti, dkk, 2015, Petunjuk Penulisan Usulan Penelitian dan Tesis, Semarang: Program Studi Magister Ilmu Hukum Unika Soegijapranata, hal. 9.

${ }^{21}$ Bambang Waluyo, op.cit., hal. 50.

22 Burhan Ashshofa, 2004, Metode Penelitian Hukum, Cetakan Keempat, Jakarta: Rineka Cipta, hal. 91.
} 
yang telah dipersiapkan sebelumnya sehingga tidak menyimpang dari tujuan wawancara yang telah ditetapkan ${ }^{23}$.

Dasar penentuan sampling untuk responden peserta Jaminan Kesehatan Nasional di Luar Wilayah Kota Semarang dengan menggunakan kriteria: Penentuan sampling berdasarkan kepemilikan Kartu Peserta Jaminan Kesehatan Nasional di Luar Wilayah dalam Kota Semarang, dan Penentuan sampling berdasarkan sudah pernah menggunakan Kartu Peserta Jaminan Kesehatan Nasional dalam mengakses pelayanan kesehatan di Puskesmas Wilayah Kota Semarang.

Lokasi penelitian adalah wilayah Kota Semarang yang meliputi BPJS Kesehatan Cabang Semarang dan Puskesmas di wilayah Kota Semarang, dan Peserta Jaminan Kesehatan Nasional di Luar Wilayah Domisili Kota Semarang. Narasumber yang diwawancarai dalam proses penelitian ini adalah: Kepala BPJS Kesehatan Kantor Cabang Semarang, dan Kepala Puskesmas yang meliputi Puskesmas Pandanaran, Puskesmas Ngesrep, Puskesmas Srondol, Puskesmas Sekaran, dan Puskesmas Kedung Mundu.

Sedangkan responden yang diwawancarai dalam penelitian ini adalah Peserta Jaminan Kesehatan Nasional di Luar Wilayah Kota Semarang yang sudah pernah memperoleh akses pelayanan kesehatan di Puskesmas Wilayah Kota Semarang sebanyak 5 responden pada setiap Puskesmas sasaran.

6. Metode Analisis Data

Dalam penelitian ini, peneliti menggunakan metode analisis data dengan pendekatan kualitatif. Metode analisis data dengan pendekatan kualitatif digunakan apabila: data yang terkumpul tidak berupa angka-angka yang dapat dilakukan pengukuran, data yang diperoleh sulit diukur dengan angka, sampel yang digunakan bersifat non probabilitas, dan pengumpulan data menggunakan pedoman wawancara dan pengamatan ${ }^{24}$.

Metode analisis data dengan pendekatan kualitatif dalam penelitian ini dilakukan dengan menganalisa hasil wawancara dari narasumber dan responden tentang Gambaran Bentuk Pengaturan tentang Prinsip Portabilitas bagi peserta Jaminan Kesehatan Nasional di luar wilayah domisili dalam memperoleh akses pelayanan kesehatan, Penerapan Prinsip Portabilitas Bagi Peserta Jaminan Kesehatan Nasional di Luar Wilayah Domisili dalam Memperoleh Akses Pelayanan Kesehatan di Kota Semarang, dan Faktor-Faktor yang Mempengaruhi Penerapan Prinsip Portabilitas Bagi Peserta Jaminan Kesehatan Nasional di Luar Wilayah Domisili dalam Memperoleh Akses Pelayanan Kesehatan di Kota Semarang. Lalu data yang diperoleh dilakukan analisa sesuai dengan bahan hukum yang digunakan dalam penelitian ini.

\section{PEMBAHASAN}

1. Bentuk Pengaturan tentang Penerapan Prinsip Portabilitas bagi Peserta JKN di Luar Wilayah Domisili dalam Memperoleh Akses Pelayanan Kesehatan di Kota Semarang.

a. Undang-Undang Dasar Negara Republik Indonesia Tahun 1945

Pengaturan penerapan prinsip portabilitas bagi peserta JKN di luar wilayah domisili dalam memperoleh akses pelayanan kesehatan di Indonesia tersirat dalam Pasal $28 \mathrm{H}$ ayat (1) dan ayat (3) serta Pasal 34 ayat (2) Undang-Undang Dasar 1945. Pasal 28H

\footnotetext{
23 Imam Gunawan, 2016, Metode Penelitian Kualitatif: Teori dan Praktik, Jakarta: Bumi Aksara, hal. 163.

24 Bambang Waluyo, op.cit., hal. 77-78.
} 
ayat (1) Undang-Undang Dasar 1945 menyatakan bahwa, "Setiap orang berhak hidup sejahtera lahir dan batin, bertempat tinggal, dan mendapatkan lingkungan hidup yang baik dan sehat serta berhak memperoleh pelayanan kesehatan"25.

Amanat pasal ini dimaksudkan bahwa hak untuk hidup sehat merupakan hak dasar yang harus dijamin, karena kesehatan merupakan bagian dari kebutuhan primer setiap manusia dan kebutuhan menuju hidup sejahtera. Hak semacam ini merupakan salah satu hak dasar atau hak asasi manusia atas pelayanan kesehatan (the right to health (are $)^{26}$.

Selain itu, dalam Pasal $28 \mathrm{H}$ ayat (3) Undang-Undang Dasar Negara Republik Indonesia Tahun 1945 disebutkan bahwa, "Setiap orang berhak atas jaminan sosial yang memungkinkan pengembangan dirinya secara utuh sebagai manusia yang bermartabat" dan kemudian dipertegas kembali dalam Pasal 34 ayat (2) yang berbunyi, "Negara mengembangkan sistem jaminan sosial bagi seluruh rakyat dan memberdayakan masyarakat yang lemah dan tidak mampu sesuai dengan martabat kemanusiaan"27.

Berdasarkan kedua pasal di atas, maka sebagai warga negara Indonesia yang menjadi peserta sistem jaminan sosial khususnya peserta JKN berhak memperoleh jaminan atas pengembangan dirinya dalam bidang kesehatan termasuk dalam memperoleh akses pelayanan kesehatan yang diselenggarakan oleh negara. Sehingga, ada jaminan dari negara sebagai tanggung jawab pemerintah terhadap penyelenggaraan Program JKN termasuk didalamnya bagi peserta JKN di luar wilayah domisili dalam memperoleh akses pelayanan kesehatan sebagai hak asasinya termasuk di Kota Semarang.

b. Undang-Undang Nomor 40 Tahun 2004 Tentang Sistem Jaminan Sosial Nasional Undang-Undang Nomor 40 Tahun 2004 Tentang Sistem Jaminan Sosial Nasional (SJSN) merupakan amanah Pasal 34 ayat (2) Undang-Undang Dasar Negara Republik Indonesia Tahun 1945. Dalam Undang-Undang SJSN ini, secara jelas disebutkan bahwa JKN merupakan salah satu jenis jaminan sosial yang bertujuan untuk menjamin terpenuhinya kebutuhan dasar kesehatan seluruh rakyat Indonesia. Program JKN ini dalam penyelenggaraannya sesuai dengan Pasal 4 huruf $f$ Undang-Undang SJSN harus berdasarkan pada dasar portabilitas. Dengan dasar atau asas portabilitas ini, peserta program JKN berhak atas akses pelayanan kesehatan yang layak untuk tetap memperoleh jaminan yang berkelanjutan atau selalu berlaku meskipun peserta tersebut domisili atau pindah tempat tinggal asalkan masih dalam lingkup wilayah Indonesia ${ }^{28}$.

Selanjutnya dalam Pasal 19 ayat (1) Undang-Undang SJSN diperjelas bahwa “jaminan kesehatan diselenggarakan secara nasional berdasarkan prinsip asuransi sosial dan

\footnotetext{
25 Undang-Undang Dasar Negara Republik Indonesia Tahun 1945 diakses dari http://jdih.pom.go.id/uud1945.pdf tanggal 01 November 2017.

${ }^{26}$ Endang Wahyati Yustina, 2015, "Hak atas Kesehatan dalam Program Jaminan Kesehatan Nasional dan Corporate Social Responsibility (CSR)", Kisi Hukum, Jurnal Ilmu Hukum Unika Soegijapranata, Vol.14, No.1 diakses dari http://journal.unika.ac.id/index.php/kh/article/view/461 tanggal 23 Maret 2018.

27 Undang-Undang Dasar Negara Republik Indonesia Tahun 1945 diakses dari http://jdih.pom.go.id/uud1945.pdf tanggal 01 November 2017.

28 Undang-Undang Nomor 40 Tahun 2004 tentang Sistem Jaminan Sosial Nasional diakses dari http://peraturan.go.id/common/dokumen/ln/2004/uu40-2004.pdf tanggal 01 November 2017.
} 
prinsip ekuitas" maka Program JKN ini harusnya dapat memenuhi prinsip portabilitas karena jaminannya dapat dirasakan di seluruh wilayah di Indonesia ${ }^{29}$.

Hal ini dimaksudkan bahwa sebagai peserta JKN, setiap orang berhak atas jaminan manfaat pemeliharaan kesehatan yang tidak terbatas hanya dalam suatu wilayah atau daerah tertentu saja misalnya di daerah tempat tinggalnya atau di FKTP terdaftarnya, tetapi dapat dimanfaatkan dimana saja di seluruh wilayah Indonesia.

c. Undang-Undang Nomor 36 Tahun 2009 Tentang Kesehatan

Undang-Undang Nomor 36 Tahun 2009 Tentang Kesehatan merupakan dasar hukum penerapan pelayanan kesehatan di Indonesia. Dalam Pasal 4 Undang-Undang Nomor 36 Tahun 2009 Tentang Kesehatan berbunyi, "Setiap orang berhak atas kesehatan" yang dijelaskan bahwa hak untuk memperoleh pelayanan kesehatan dari fasilitas pelayanan kesehatan agar dapat mewujudkan derajat kesehatan yang setinggitingginya $a^{30}$.

Hak untuk memperoleh pelayanan kesehatan yang paripurna juga terkait kemudahan akses terhadap fasilitas pelayanan kesehatan yang dibutuhkan tak terkecuali Puskesmas. Akses atau keterjangkauan pelayanan kesehatan adalah pelayanan kesehatan harus dapat dicapai oleh masyarakat, tanpa terhalang oleh keadaan geografis, sosial, ekonomi, organisasi, dan bahasa ${ }^{31}$. Sehingga ada kemudahan akses pelayanan kesehatan termasuk akses ke fasilitas pelayanan yang mudah.

Penyelenggaraan Program JKN berdasarkan prinsip portabilitas mengakibatkan masyarakat Indonesia yang telah menjadi peserta JKN tanpa terkecuali juga termasuk yang sedang berada di luar wilayah domisilipun memiliki hak yang sama untuk memperoleh akses pelayanan kesehatan termasuk di puskesmas. Puskesmas sebagai salah satu fasilitas kesehatan tingkat pertama milik pemerintah di era JKN yang juga memberikan pelayanan kesehatan perorangan harusnya menyelenggarakan pelayanan kesehatan yang berdasarkan prinsip portabilitas bagi peserta JKN luar wilayah domisili di Kota Semarang.

d. Undang-Undang Nomor 24 Tahun 2011 Tentang Badan Penyelenggara Jaminan Sosial Undang-Undang Nomor 24 Tahun 2011 Tentang Badan Penyelenggara Jaminan Sosial (BPJS) merupakan peraturan pelaksanaan Undang-Undang Nomor 40 Tahun 2004 Tentang Sistem Jaminan Sosial Nasional atau UU SJSN. Dalam Pasal 9 ayat (1) Undang-Undang BPJS disebutkan bahwa BPJS Kesehatan berfungsi menyelenggarakan program jaminan kesehatan. Sehingga dalam penyelenggaraannya, BPJS Kesehatan juga tunduk terhadap prinsip portabilitas yang tertuang dalam Pasal 4 huruf f Undang-Undang Nomor 24 Tahun 2011 Tentang Badan Penyelenggaraan Jaminan Sosial ${ }^{32}$.

Karena prinsip portabilitas tersebut, peserta harus selalu terjamin atau terlndungi kapan dan dimanapun dia berada selama di dalam yurisdiksi Indonesia. Peserta yang berpindah pekerjaan atau berpindah tempat tinggal dalam wilayah Negara Kesatuan

\footnotetext{
29Undang-Undang Nomor 40 Tahun 2004 tentang Sistem Jaminan Sosial Nasional diakses dari http://peraturan.go.id/common/dokumen/ln/2004/uu40-2004.pdf tanggal 01 November 2017.

30Undang-Undang Nomor 36 Tahun 2009 tentang Kesehatan diakses dari http://peraturan.go.id/common/dokumen/ln/2009/uu36-2009.pdf tanggal 07 April 2017.

31 Imbalo S. Pohan, op.cit., hal.20.

${ }^{32}$ Undang-Undang Nomor 24 Tahun 2011 tentang Badan Penyelenggara Jaminan Sosial diakses dari http://bpjskesehatan.go.id/bpjs/index.php/unduh/index/1 pada tanggal o1 November 2017.
} 
Republik Indonesia harus selalu terlindungi. Atau ketika peserta sedang bepergian di luar wilayah tempat tinggal atau tempat kerja, jaminan harus tetap berlaku. Sebab ketika orang sakit, maka sakit adalah pencetus (triger) untuk mendapatkan hak jaminan kesehatan maka BPJS tidak boleh membatasi jaminan pada suatu wilayah tertentu ${ }^{33}$.

Hal ini sejalan dengan salah satu kewajiban BPJS termasuk BPJS Kesehatan yang tertuang dalam Pasal 13 huruf d Undang-Undang Nomor 24 Tahun 2011 Tentang Badan Penyelenggaraan Jaminan Sosial bahwa memberikan manfaat kepada seluruh peserta sesuai dengan Undang-Undang tentang Sistem Jaminan Sosial Nasional ${ }^{34}$. Manfaat tersebut sesuai dengan Pasal 22 ayat (1) Undang-Undang Nomor 40 Tahun 2004 Tentang Sistem Jaminan Sosial Nasional adalah manfaat jaminan kesehatan bersifat pelayanan perseorangan berupa pelayanan kesehatan yang mencakup pelayanan promotif, preventif, kuratif, dan rehabilitatif, termasuk obat dan bahan medis habis pakai yang diperlukan ${ }^{35}$.

Dalam Pasal 23 ayat (1) Undang-Undang Nomor 40 Tahun 2004 Tentang Sistem Jaminan Sosial Nasional lebih lanjut menyebutkan bahwa manfaat jaminan kesehatan sebagaimana dimaksud dalam Pasal 22 diberikan pada fasilitas kesehatan milik Pemerintah atau swasta yang menjalin kerjasama dengan Badan Penyelenggara Jaminan Sosial. Fasilitas kesehatan tersebut dalam penjelasan Pasal 23 ayat (1) Undang-Undang Nomor 40 Tahun 2004 Tentang Sistem Jaminan Sosial Nasional meliputi rumah sakit, dokter praktek, klinik, laboratorium, apotek dan fasilitas kesehatan lainnya. Fasilitas kesehatan memenuhi syarat tertentu apabila fasilitas kesehatan tersebut diakui dan memiliki izin dari instansi Pemerintah yang bertanggung jawab di bidang kesehatan ${ }^{36}$.

Maka, puskesmas sebagai salah satu fasilitas kesehatan milik Pemerintah yang tentu saja menjalin kerjasama dengan BPJS Kesehatan dalam menyelenggarakan pelayanan kesehatan kepada peserta JKN termasuk peserta JKN luar wilayah domisili senantiasa berlandaskan pada prinsip portabilitas.

e. Peraturan Presiden Nomor 19 Tahun 2016 Tentang Perubahan Kedua Atas Peraturan Presiden Nomor 12 Tahun 2013 Tentang Jaminan Kesehatan Jaminan kesehatan pada Pasal 1 angka 1 Peraturan Presiden Nomor 19 Tahun 2016 Tentang Perubahan Kedua Atas Peraturan Presiden Nomor 12 Tahun 2013 Tentang Jaminan Kesehatan didefinisikan sebagai “jaminan berupa perlindungan kesehatan agar peserta memperoleh manfaat pemeliharaan kesehatan dan perlindungan dalam memenuhi kebutuhan dasar kesehatan yang diberikan kepada setiap orang yang telah membayar iuran atau iurannya dibayar oleh pemerintah" 37.

\footnotetext{
33 Hasbullah Thabrany, op.cit., hal.173-174.

34 Undang-Undang Nomor 24 Tahun 2011 tentang Badan Penyelenggara Jaminan Sosial diakses dari http://bpjskesehatan.go.id/bpjs/index.php/unduh/index/1 pada tanggal 01 November 2017.

35 Undang-Undang Nomor 40 Tahun 2004 tentang Sistem Jaminan Sosial Nasional diakses dari http://peraturan.go.id/common/dokumen/In/2004/uu40-2004.pdf tanggal 01 November 2017.

${ }^{36}$ Undang-Undang Nomor 40 Tahun 2004 tentang Sistem Jaminan Sosial Nasional diakses dari http://peraturan.go.id/common/dokumen/ln/2004/uu40-2004.pdf tanggal 01 November 2017.

37Peraturan Presiden Nomor 19 Tahun 2016 tentang Perubahan Kedua atas Peraturan Presiden Nomor 12 Tahun 2013 tentang Jaminan Kesehatan diakses dari http://peraturan.go.id/common/dokumen/ln/2016/ps19-2016.pdf tanggal 17 April 2018.
} 
Berdasarkan definisi di atas, maka jaminan kesehatan yang dimaksud merupakan hak setiap peserta JKN. Hak tersebut diperoleh melalui BPJS Kesehatan sebagai penyelenggara Program JKN bekerjasama dengan fasilitas kesehatan berupa manfaat pemeliharaan kesehatan dan perlindungan dalam memenuhi kebutuhan dasar kesehatan yang sesuai.

Pada Pasal 29 ayat (3) Peraturan Presiden Nomor 19 Tahun 2016 Tentang Perubahan Kedua Atas Peraturan Presiden Nomor 12 Tahun 2013 Tentang Jaminan Kesehatan ini disebutkan tata cara pemanfaatan akses pelayaanan kesehatan dilakukan dengan "Peserta harus memperoleh pelayanan kesehatan pada Fasilitas Kesehatan tingkat pertama tempat Peserta terdaftar" namun dalam ayat (4) huruf a dijabarkan lebih lanjut bahwa "Dalam keadaan tertentu, ketentuan sebagaimana dimaksud pada ayat (3) tidak berlaku bagi Peserta yang berada di luar wilayah Fasilitas Kesehatan tingkat pertama tempat Peserta terdaftar"38.

Sesuai dengan kedua ayat tersebut di atas dalam Peraturan Presiden Nomor 19 Tahun 2016 Tentang Perubahan Kedua Atas Peraturan Presiden Nomor 12 Tahun 2013 Tentang Jaminan Kesehatan, peserta JKN dalam memanfaatkan pelayanan kesehatan tidak hanya terbatas pada FKTP dimana Peserta terdaftar tetapi bisa juga dimanfaatkan di luar FKTP terdaftar. Ini menunjukkan bahwa dalam Program JKN, peserta JKN boleh memperoleh prinsip portabilitas dalam memanfaatkan pelayanan kesehatan baik di FKTP terdaftar maupun di luar FKTP terdaftar. Sehingga kedua ayat ini merupakan bentuk dasar pengaturan penerapan prinsip portabilitas bagi peserta Jaminan Kesehatan Nasional di luar wilayah domisili dalam memperoleh akses pelayanan kesehatan di Kota Semarang.

f. Peraturan Presiden Nomor 82 Tahun 2018 Tentang Jaminan Kesehatan Tanggal 18 September 2018 diundangkan Peraturan Presiden Nomor 82 Tahun 2018 Tentang Jaminan Kesehatan yang merupakan perubahan ketiga atas Peraturan Presiden Nomor 12 Tahun 2013 Tentang Jaminan Kesehatan. Namun, saat penelitian ini berlangsung masih berlaku Peraturan Presiden Nomor 19 Tahun 2016 Tentang Perubahan Kedua Atas Peraturan Presiden Nomor 12 Tahun 2013 Tentang Jaminan Kesehatan. Dalam hal ini peneliti menggunakan Peraturan Presiden Nomor 82 Tahun 2018 Tentang Jaminan Kesehatan sebagai pembanding terhadap bentuk pengaturan lainnya yang sedang berlaku saat penelitian berlangsung.

Dalam Pasal 55 Peraturan Presiden Nomor 82 Tahun 2018 Tentang Jaminan Kesehatan ini ada diatur tentang penerapan prinsip portabilitas bagi peserta JKN di luar wilayah domisili dalam memperoleh akses pelayanan kesehatan di FKTP terutama Puskemas, yaitu sebagai berikut:

(1) Pelayanan kesehatan bagi Peserta dilaksanakan secara berjenjang sesuai kebutuhan medis dan kompetensi Fasilitas Kesehatan dimulai dari FKTP Peserta terdaftar, kecuali dalam keadaan kegawatdaruratan medis.

(2) Pelayanan kesehatan tingkat pertama bagi Peserta dilaksanakan di FKTP tempat Peserta terdaftar, kecuali bagi Peserta yang:

a. berada di luar wilayah FKTP tempat Peserta terdaftar; atau

\footnotetext{
38 Peraturan Presiden Nomor 19 Tahun 2016 tentang Perubahan Kedua atas Peraturan Presiden Nomor 12 Tahun 2013 tentang Jaminan Kesehatan diakses dari http://peraturan.go.id/common/dokumen/ln/2016/ps19-2016.pdf tanggal 17 April 2018.
} 
b. dalam keadaan kegawatdaruratan medis.

(3) Peserta yang berada di luar wilayah FKTP tempat Peserta terdaftar sebagaimana dimaksud pada ayat (2) huruf a dapat mengakses pelayanan rawat jalan tingkat pertama pada FKTP lain untuk paling banyak 3 (tiga) kali kunjungan dalam waktu paling lama 1 (satu) bulan di FKTP yang sama.

(4)Dalam hal Peserta memerlukan pelayanan kesehatan tingkat lanjutan, FKTP wajib merujuk ke FKRTL sesuai dengan kasus dan kompetensi Fasilitas Kesehatan serta sistem rujukan.

(5)Pelayanan yang diberikan kepada Peserta yang dirujuk ke FKRTL sebagaimana dimaksud pada ayat (4) dilakukan paling lama 3 (tiga) bulan ${ }^{39}$.

Berdasarkan ketentuan-kentuan di atas, bila dibandingkan dengan ketentuanketentuan dalam Peraturan Presiden Nomor 19 Tahun 2016 yang mengatur hal yang sama terdapat perbedaan yaitu bahwa dalam Peraturan Presiden Nomor 82 Tahun 2018 Tentang Jaminan Kesehatan ini terutama pada Pasal 55 ayat (3) secara gamblang menyebutkan bahwa peserta luar wilayah FKTP dapat mengakses pelayanan rawat jalan tingkat pertama di FKTP lain paling banyak 3 (tiga) kali kunjungan dalam waktu paling lama 1 (satu) bulan di FKTP yang sama ${ }^{40}$, sedangkan dalam Peraturan Presiden Nomor 19 Tahun 2016 belum disebutkan secara jelas batasan akses peserta JKN luar FKTP. Hal ini tentu saja memberikan kepastian hukum bagi Peserta JKN luar wilayah FKTP terutama di luar wilayah domisilinya dalam memperoleh akses pelayanan kesehatan juga bagi FKTP dalam memberikan akses pelayanan kesehatan kepada Peserta JKN luar wilayah FKTP. Dalam pembahasan penelitian ini, peneliti hanya akan membahas bentuk pengaturan penerapan prinsip portabilitas bagi peserta JKN di luar wilayah domisili dalam memperoleh akses pelayanan kesehatan di Kota Semarang pada Peraturan Presiden Nomor 82 Tahun 2018 Tentang Jaminan Kesehatan karena saat penelitian berlangsung masih berlaku Peraturan Presiden Nomor 19 Tahun 2016 Tentang Perubahan Kedua Atas Peraturan Presiden Nomor 12 Tahun 2013 Tentang Jaminan Kesehatan. Karena ketika ketentuan dalam Peraturan Presiden Nomor 82 Tahun 2018 Tentang Jaminan Kesehatan ini berlaku maka Peraturan Presiden Nomor 19 Tahun 2016 Tentang Perubahan Kedua Atas Peraturan Presiden Nomor 12 Tahun 2013 Tentang Jaminan Kesehatan dan Surat Edaran BPJS Kesehatan Kantor Cabang Semarang Nomor 766/VI-01/0518 tentang Pelayanan Peserta Luar Wilayah di FKTP batal demi hukum dan tidak berlaku.

g. Peraturan Menteri Kesehatan Nomor 99 Tahun 2015 Tentang Perubahan Atas Peraturan Menteri Kesehatan Nomor 71 Tahun 2013 Tentang Pelayanan Kesehatan Pada Jaminan Kesehatan Nasional

Pelayanan kesehatan pada Prorgam JKN merupakan sistem pelayanan yang berjenjang dimulai dari FKTP meliputi Puskesmas. Dalam Pasal 3 Peraturan Menteri Kesehatan Nomor 99 Tahun 2015 Tentang Perubahan Atas Peraturan Menteri Kesehatan Nomor 71 Tahun 2013 Tentang Pelayanan Kesehatan Pada Jaminan Kesehatan Nasional, FKTP yang bekerjasama dengan BPJS Kesehatan harus menyelenggarakan pelayanan kesehatan kompherensif artinya pelayanan kesehatan

\footnotetext{
39Peraturan Presiden Nomor 82 Tahun 2018 tentang Jaminan Kesehatan diakses dari http://peraturan.go.id/common/dokumen/ln/2018/ps82-2018.pdf pada tanggal 28 November 2018.

40Peraturan Presiden Nomor 82 Tahun 2018 tentang Jaminan Kesehatan diakses dari http://peraturan.go.id/common/dokumen/In/2018/ps82-2018.pdf pada tanggal 28 November 2018.
} 
promotif, preventif, kuratif, rehabilitatif, pelayanan kebidanan, dan pelayanan kesehatan darurat medis, termasuk pelayanan penunjang diagnostik laboratorium tingkat pertama dan pelayanan kefarmasian ${ }^{41}$. Sehingga, puskesmas sebagai partner BPJS Kesehatan harus mampu memberikan pelayanan kesehatan kompherensif kepada peserta JKN.

Pada Pasal 13 ayat (1) Peraturan Menteri Kesehatan Nomor 99 Tahun 2015 Tentang Perubahan Atas Peraturan Menteri Kesehatan Nomor 71 Tahun 2013 Tentang Pelayanan Kesehatan Pada Jaminan Kesehatan Nasional disebutkan bahwa "Setiap Peserta berhak memperoleh pelayanan kesehatan yang mencakup pelayanan promotif, preventif, kuratif, dan rehabilitatif termasuk pelayanan obat dan bahan medis habis pakai sesuai dengan kebutuhan medis yang diperlukan" ${ }^{42}$.

Prosedur untuk memperoleh akses pelayanan kesehatan dalam Program JKN dijelaskan pada Pasal 14 ayat (2) Peraturan Menteri Kesehatan Nomor 99 Tahun 2015 Tentang Perubahan Atas Peraturan Menteri Kesehatan Nomor 71 Tahun 2013 Tentang Pelayanan Kesehatan Pada Jaminan Kesehatan Nasional disebutkan bahwa "Pelayanan Kesehatan Tingkat Pertama bagi Peserta diselenggarakan oleh Fasilitas Kesehatan tingkat pertama tempat Peserta terdaftar". Namun ada pengecualian dalam Pasal 14 ayat (3) huruf a Peraturan Menteri Kesehatan Nomor 99 Tahun 2015 Tentang Perubahan Atas Peraturan Menteri Kesehatan Nomor 71 Tahun 2013 Tentang Pelayanan Kesehatan Pada Jaminan Kesehatan Nasional yaitu "Dalam keadaan tertentu, ketentuan sebagaimana dimaksud pada ayat (2) tidak berlaku bagi Peserta yang berada di luar wilayah Fasilitas Kesehatan tingkat pertama tempat Peserta terdaftar" sehingga Peserta JKN selama masih berada dalam wilayah NKRI, dapat memperoleh akses pelayanan kesehatan di Fasilitas Kesehatan tingkat pertama dimanapun selama Fasilitas Kesehatan tersebut menjalin kerjasama dengan BPJS Kesehatan ${ }^{43}$.

Sesuai dengan ketentuan-ketentuan di atas, maka penerapan prinsip portabilitas bagi peserta Jaminan Kesehatan Nasional di luar wilayah domisili dalam memperoleh akses pelayanan kesehatan di Indonesia termasuk Kota Semarang dapat terlaksana.

h. Peraturan Badan Penyelenggara Jaminan Sosial Kesehatan Nomor 1 Tahun 2014 Tentang Penyelenggaraan Jaminan Kesehatan

Dalam Peraturan Badan Penyelenggaraan Jaminan Sosial Kesehatan Nomor 1 Tahun 2014 Tentang Penyelenggaraan Jaminan Kesehatan terutama pada Pasal 26 huruf b secara jelas disebutkan bahwa setiap peserta wajib melaporkan perubahan data kepesertaan. Perubahan data kepesertaan ini dijabarkan dalam Pasal 27 ayat (1) dan ayat (2) Peraturan Badan Penyelenggaraan Jaminan Sosial Kesehatan Nomor 1 Tahun 2014 Tentang Penyelenggaraan Jaminan Kesehatan adalah meliputi fasilitas kesehatan tingkat pertama, tempat tinggal, tempat bekerja dan/atau identitas

\footnotetext{
${ }^{41}$ Peraturan Menteri Kesehatan Nomor 99 Tahun 2015 tentang Perubahan Atas Peraturan Menteri Kesehatan Nomor 71 Tahun 2013 tentang Pelayanan Kesehatan pada Jaminan Kesehatan Nasional diakses dari http://peraturan.go.id/common/dokumen/bn/2016/bn15-2016.pdf tanggal 28 November 2018.

42 Peraturan Menteri Kesehatan Nomor 99 Tahun 2015 tentang Perubahan Atas Peraturan Menteri Kesehatan Nomor 71 Tahun 2013 tentang Pelayanan Kesehatan pada Jaminan Kesehatan Nasional diakses dari http://peraturan.go.id/common/dokumen/bn/2016/bn15-2016.pdf tanggal 28 November 2018.

43 Peraturan Menteri Kesehatan Nomor 99 Tahun 2015 tentang Perubahan Atas Peraturan Menteri Kesehatan Nomor 71 Tahun 2013 tentang Pelayanan Kesehatan pada Jaminan Kesehatan Nasional diakses dari http://peraturan.go.id/common/dokumen/bn/2016/bn15-2016.pdf tanggal 28 November 2018.
} 
Pemberi Kerja baru, golongan kepegawaian, jenis kepesertaan, susunan keluarga dan/atau jumlah peserta, dan anggota kelurga tambahan wajib dilaporkan kepada BPJS Kesehatan ${ }^{44}$.

Berdasarkan kedua Pasal tersebut di atas, peserta JKN dapat melakukan perubahan data kepesertaan termasuk berpindah FKTP, tempat tinggal atau domisili dan juga tempat bekerja baru asalkan peserta JKN melaporkannya kepada BPJS Kesehatan. Dengan melaporkan perubahan data kepesertaan kepada BPJS Kesehatan, peserta JKN di luar wilayah domisili dapat memperoleh akses pelayanan kesehatan di FKTP pilihan sesuai dengan perubahan wilayah tempat tinggal atau domisilinya.

Hal ini juga sesungguhya telah diatur dalam Pasal 48 ayat (1) Peraturan Badan Penyelenggaraan Jaminan Sosial Kesehatan Nomor 1 Tahun 2014 Tentang Penyelenggaraan Jaminan Kesehatan bahwa Pelayanan kesehatan pada fasilitas kesehatan tingkat pertama bagi Peserta dilakukan oleh fasilitas kesehatan tingkat pertama tempat Peserta terdaftar selanjutnya dalam ayat (2) dijabarkan lebih lanjut bahwa Peserta sebagaimana dimaksud pada ayat (1) dapat memilih fasilitas kesehatan tingkat pertama yang lain dalam jangka waktu paling sedikit 3 (tiga) bulan ${ }^{45}$.

Artinya peserta JKN dalam memperoleh akses pelayanan kesehatan pertama kali harus sesuai dengan FKTP terdaftar peserta di awal dan setelah tiga bulan kemudian peserta boleh memilih FKTP lain. FKTP dimaksud adalah FKTP yang telah menjalin kerjasama dengan BPJS Kesehatan dalam Pasal 48 ayat (3) Peraturan Badan Penyelenggaraan Jaminan Sosial Kesehatan Nomor 1 Tahun 2014 Tentang Penyelenggaraan Jaminan Kesehatan terdiri dari Puskesmas atau yang setara, praktik dokter, praktik dokter gigi, klinik pratama atau yang setara termasuk fasilitas kesehatan tingkat pertama milik TNI/POLRI, dan Rumah Sakit kelas D pratama atau yang setara ${ }^{46}$. Sehingga Peserta JKN bebas memilih salah satu FKTP sesuai keinginannya termasuk boleh memilih Puskesmas mana sebagai FKTP pilihannya dalam memperoleh akses pelayanan kesehatan.

i. Surat Edaran BPJS Kesehatan Kantor Cabang Semarang Nomor 766/vi-01/0518 tentang Pelayanan Peserta Luar Wilayah di FKTP

Dalam Surat Edaran tersebut secara khusus membahas pelayanan kesehatan bagi peserta JKN yang berasal dari luar wilayah dalam memperoleh akses pelayanan kesehatan di FKTP Wilayah Kerja BPJS Kesehatan Kantor Cabang Semarang.

Berdasarkan penjelasan dalam Surat Edaran BPJS Kesehatan Kantor Cabang Semarang Nomor 766/VI-01/0518 tentang Pelayanan Peserta Luar Wilayah di FKTP maka peserta JKN yang sedang berada di luar wilayah domisilinya termasuk di Kota Semarang dapat memperoleh akses pelayanan kesehatan. Akses pelayanan kesehatan tersebut dapat diperoleh di FKTP terdekat maksimal tiga (3) kali kunjungan atau tiga (3) bulan berada di wilayah domisili Kota Semarang tanpa membawa surat pengantar sementara dari BPJS Kesehatan atau tanpa melaporkan secara langsung ke BPJS Kesehatan Kantor Cabang

\footnotetext{
44 Peraturan Badan Penyelenggara Jaminan Sosial Kesehatan Nomor 1 Tahun 2014 tentang Penyelenggara Jaminan Kesehatan diakses dari http://bpjs-kesehatan.go.id/bpjs/arsip/view/10 tanggal 17 April 2018.

45 Peraturan Badan Penyelenggara Jaminan Sosial Kesehatan Nomor 1 Tahun 2014 tentang Penyelenggara Jaminan Kesehatan diakses dari http://bpjs-kesehatan.go.id/bpjs/arsip/view/10 tanggal 17 April 2018.

46 Peraturan Badan Penyelenggara Jaminan Sosial Kesehatan Nomor 1 Tahun 2014 tentang Penyelenggara Jaminan Kesehatan diakses dari http://bpjs-kesehatan.go.id/bpjs/arsip/view/10 tanggal 17 April 2018.
} 
Semarang. Namun bila peserta JKN akan memanfaatkan akses pelayanan kesehatan di FKTP tersebut lebih dari tiga (3) kali kunjungan atau tiga (3) bulan maka peserta harus memindahkan FKTPnya ke FKTP tersebut dan atau melaporkan ke BPJS Kesehatan Kantor Cabang Semarang untuk memperoleh surat pengantar.

Kemudahan akses pelayanan kesehatan ini seharusnya sudah melekat sejak seseorang menjadi peserta JKN karena salah satu prinsip penyelenggaraan SJSN termasuk JKN yang diselenggarakan oleh BPJS Kesehatan adalah prinsip portabilitas. Prinsip portabilitas dalam Pasal 4 huruf $f$ Undang-Undang Sistem Jaminan Sosial Nasional dan Pasal 4 huruf $f$ Undang-Undang Badan Penyelenggara Jaminan Sosial didefinisikan sebagai prinsip memberikan jaminan yang berkelanjutan meskipun peserta berpindah pekerjaan atau tempat tinggal dalam wilayah Negara Kesatuan Republik Indonesia. Dan karena prinsipnya tersebut, peserta harus selalu terjamin atau terlindungi kapan dan dimanapun dia berada di dalam yurisdiksi Indonesia ${ }^{47}$.

Berdasarkan pembahasan di atas diperoleh hasil bahwa sudah ada bentuk pengaturan tentang penerapan prinsip portabilitas bagi peserta JKN di luar wilayah domisili dalam memperoleh akses pelayanan kesehatan di Kota Semarang yang dimulai dari Undang-Undang Dasar 1945, Undang-Undang SJSN, Undang-Undang Kesehatan, Undang-Undang BPJS, Perpres Nomor 19 Tahun 2016 tentang Perubahan Kedua atas Perpres Nomor 12 Tahun 2013 tentang Jaminan Kesehatan, Perpres Nomor 82 Tahun 2018 tentang Jaminan Kesehatan, Permenkes Nomor 99 Tahun 2015 tentang Perubahan atas Permenkes Nomor 71 Tahun 2013 tentang Pelayanan Kesehatan pada Jaminan Kesehatan Nasional, Peraturan BPJS Kesehatan Nomor 1 Tahun 2014 tentang Penyelenggaraan Jaminan Kesehatan sampai dengan Surat Edaran BPJS Kesehatan Kantor Cabang Semarang Nomor 766/VI-01/0518 tentang Pelayanan Peserta Luar Wilayah di FKTP.

Karena penerapan prinsip portabilitas di Kota Semarang masih didasarkan pada Surat Edaran BPJS Kesehatan Kantor Cabang Semarang Nomor 766/VI-01/0518 tentang Pelayanan Peserta Luar Wilayah di FKTP yang sesungguhnya tidak bersifat mengikat maka diperlukan Peraturan teknis yang mengatur tentang penerapan prinsip portabilitas bagi peserta JKN di luar wilayah domisili dalam memperoleh akses pelayanan kesehatan berupa Keputusan Menteri. Adanya Keputusan Menteri dapat mengikat para pihak di dalamnya secara hukum dan sekaligus memberikan kepastian hukum bagi para pihak seperti FKTP termasuk Puskesmas dan Peserta JKN luar wilayah domisili juga BPJS Kesehatan.

Keputusan Menteri tersebut dapat menjadi petunjuk penerapan prinsip portabilitas bagi peserta JKN di luar wilayah domisili dalam memperoleh akses pelayanan kesehatan di Indonesia termasuk di Kota Semarang yang mengikat FKTP termasuk kelima Puskesmas yang diteliti, BPJS Kesehatan Kantor Cabang Semarang dan peserta JKN luar wilayah domisili yang berada di Kota Semarang. Berbeda bila petunjuk teknis penerapannya hanya berdasarkan Surat Edaran yang tidak memiliki kekuatan hukum mengikat.

Selain itu, dalam pemanfaatan Aplikasi Mobile JKN belum ada bentuk pengaturan atau produk hukum yang mengatur terkait kelegalannya dan prosedur pemanfaatannya sehingga dapat digunakan untuk memudahkan peserta JKN saat mengakses

47 Hasbullah Thabrany, op.cit., hal.155. 
pelayanan kesehatan dengan aplikasi tersebut termasuk bagi peserta JKN luar wilayah domisili dalam memindahkan FKTPnya.

2. Penerapan Prinsip Portabilitas bagi Peserta JKN di Luar Wilayah Domisili dalam Memperoleh Akses Pelayanan Kesehatan di Kota Semarang

a. Persyaratan penerapan prinsip portabilitas bagi peserta JKN di luar wilayah domisili dalam memperoleh akses pelayanan kesehatan di Kota Semarang

Persyaratan penerapan prinsip portabilitas bagi peserta JKN di luar wilayah domisili dalam memperoleh akses pelayanan kesehatan di Kota Semarang terutama di kelima Puskesmas yang diteliti sebagai FKTP secara umum adalah sebagai berikut:

Peserta JKN yang dimaksud adalah peserta JKN aktif, peserta yang tidak sedang menunggak iuran baik peserta PBI, peserta bukan PBI; Peserta JKN dari luar wilayah Kota Semarang yang sedang domisili di Kota Semarang dengan berbagai tujuan: pindah tempat kerja, liburan, kuliah, dan bekerja; serta Peserta JKN yang memiliki kartu JKN baik fisik maupun digital.

Ketiga persyaratan di atas merupakan persyaratan yang ditemukan peneliti saat penelitian di kelima Puskesmas yang diteliti. Berdasarkan ketiga persyaratan ini, peserta JKN luar wilayah domisili Kota Semarang dapat memperoleh akses pelayanan kesehatan di Puskesmas berdasarkan prinsip portabilitas tersebut. Peserta JKN luar wilayah domisili Kota Semarang sesuai hasil penelitian berasal dari Jogjakarta, Medan, Kalimantan, Bandungan, Tegal, Bima, dan beberapa kota lain di Indonesia sudah memenuhi ketiga persyaratan di atas maka peserta berhak memperoleh akses pelayanan kesehatan di Puskemas tanpa membayar biaya pelayanan.

Persyaratan tersebut belum diatur dalam bentuk pengaturan tentang penerapan prinsip portabilitas bagi peserta JKN luar wilayah domisili dalam memperoleh akses pelayanan kesehatan. Perlu adanya peraturan teknis yang mengatur secara jelas tentang persyaratan penerapan prinsip portabilitas bagi peserta JKN di luar wilayah domisili dalam memperoleh akses pelayanan kesehatan melalui Keputusan Menteri sehingga memberikan kejelasan dan kepastian hukum bagi BPJS Kesehatan termasuk BPJS Kesehatan Kantor Cabang Semarang, Puskesmas sebagai FKTP, dan peserta JKN luar wilayah domisili terutama di Kota Semarang.

Adanya pengaturan yang jelas tentang persyaratan penerapan prinsip portabilitas bagi peserta JKN di luar wilayah domisili dalam memperoleh akses pelayanan kesehatan akan memudahkan dalam penerapannya termasuk di Kota Semarang.

b. Prosedur administrasi penerapan prinsip portabilitas bagi peserta JKN di luar wilayah domisili dalam memperoleh akses pelayanan kesehatan di Kota Semarang

Sesuai hasil penelitian, prosedur administratif penerapan prinsip portabilitas bagi peserta JKN luar wilayah domisili dalam memperoleh akses pelayanan kesehatan di Puskesmas sebagai FKTP adalah

1) Menunjukkan kartu JKN baik fisik maupun digital saat pendaftaran. Kartu JKN digital merupakan bentuk legal bagi peserta JKN dalam memperoleh akses pelayanan kesehatan sehingga peserta boleh menggunakannya.

2) Petugas melakukan verifikasi dengan meng-input data peserta dalam Aplikasi Pcare yang memuat semua data peserta tersebut termasuk apakah ada tagihan 
atau tidak, sudah memanfaatkan pelayanan kesehatan berapa kali dan dimana, serta apakah peserta boleh memanfaatkan akses pelayanan kesehatan di Puskesmas tujuan. Sesuai dengan isi Surat Edaran dari BPJS Kesehatan Kantor Cabang Semarang Nomor 766/VI-01/0518, peserta yang memperoleh akses pelayanan kesehatan ke bukan FKTP terdaftar lebih dari 3 kali maka Aplikasi Pcare akan otomatis menolak inputan data peserta.

3) Bila tidak ditemukan permasalahan, maka peserta boleh memperoleh akses pelayanan kesehatan ke poli tujuan di Puskesmas sesuai dengan kebutuhan peserta hingga selesai.

Ketiga prosedur administratif di atas merupakan temuan prosedur administratif penerapan prinsip portabilitas bagi peserta JKN luar wilayah domisili Kota Semarang dalam memperoleh akses pelayanan kesehatan di kelima Puskesmas. Prosedur tersebut juga belum ditemukan dalam bentuk pengaturan penerapan prinsip portabilitas bagi peserta JKN di luar wilayah domisili dalam memperoleh akses pelayanan kesehatan sehingga diperlukan peraturan teknis yang memuat secara lengkap dan jelas prosedur administratif tersebut. Peraturan teknis tersebut dapat berupa Keputusan Menteri bukan Surat Edaran yang tidak dapat mengikat. Peraturan teknis tersebut harus memuat tentang prosedur pemanfaatan kartu JKN digital dalam Aplikasi Mobile JKN karena dalam bentuk pengaturan penerapan prinsip portabilitas bagi peserta JKN di luar wilayah domisili dalam memperoleh akses pelayanan kesehatan belum ada peraturan yang menetapkan kartu JKN digital sebagai bentuk legal disamping pemanfaatan kartu JKN fisik.

Berdasarkan pembahasan di atas, penerapan prinsip portabilitas bagi peserta JKN di luar wilayah domisili dalam memperoleh akses pelayanan kesehatan di Kota Semarang saat ini belum memiliki prosedur administratif yang baku dalam peraturan perundang-undangan dan bersifat mengikat sehingga diperlukan peraturan teknis berupa Keputusan Menteri.

c. Prosedur layanan penerapan prinsip portabilitas bagi peserta JKN di luar wilayah domisili dalam memperoleh akses pelayanan kesehatan di Kota Semarang

Pelayanan kesehatan bagi peserta JKN adalah berjenjang dimulai dari FKTP termasuk Puskesmas. Prosedur layanan kesehatan umumnya bagi peserta JKN adalah dilakukan pada FKTP peserta terdaftar. Pengecualian sesuai dengan Perpres Nomor 19 Tahun 2016 tentang Perubahan Kedua atas Perpres Nomor 12 Tahun 2013 tentang Jaminan Kesehatan terutama dalam Pasal 29 ayat (4) yang memperbolehkan peserta JKN luar wilayah domisili FKTP terdaftar untuk memperoleh akses pelayanan kesehatan di luar FKTP terdaftar ${ }^{48}$.

Hal ini menunjukkan bahwa peserta JKN sesuai dengan prinsip portabilitas dapat memperoleh akses pelayanan kesehatan di luar FKTP terdaftar. Prosedur layanan penerapan prinsip portabilitas bagi peserta JKN di luar wilayah domisili dalam memperoleh akses pelayanan kesehatan di Kota Semarang terutama di kelima Puskesmas sesuai dengan Pasal 29 ayat (1), ayat (2), ayat (3), ayat (4), dan ayat (5) Perpres Nomor 19 Tahun 2016 tentang Perubahan Kedua atas Perpres Nomor 12 Tahun 2013 tentang Jaminan Kesehatan dan Pasal 14 ayat (1), ayat (2), ayat (3), dan ${ }^{48}$ Peraturan Presiden Nomor 12 Tahun 2013 tentang Jaminan Kesehatan diakses dari
http://peraturan.go.id/common/dokumen/ln/2013/ps12-2013.pdf tanggal 17 April 2018. 
ayat (4) Permenkes Nomor 99 Tahun 2015 tentang Perubahan atas Permenkes Nomor 71 Tahun 2013 tentang Pelayanan Kesehatan pada Jaminan Kesehatan Nasional.

Kedua peraturan ini memuat hal yang sama bahwa prosedur layanan penerapan prinsip portabilitas bagi peserta JKN di luar wilayah domisili dalam memperoleh akses pelayanan kesehatan di FKTP termasuk Puskesmas diterapkan bagi Peserta JKN di luar FKTP terdaftar atau dalam kegawatdaruratan medis. Selain itu, prosedur layanan tersebut ditetapkan dalam Surat Edaran dari BPJS Kesehatan Kantor Cabang Semarang Nomor 766/VI-01/0518 tentang Pelayanan Peserta luar wilayah FKTP. Peserta JKN luar wilayah domisili Kota Semarang dalam memperoleh akses pelayanan kesehatan di luar FKTP maksimal 3 (tiga) kali kunjungan tanpa membayar biaya pelayanan. Peserta yang berada di luar wilayah domisili lebih dari 3 (tiga) bulan atau sudah melakukan kunjungan 3 (tiga) kali disarankan untuk pindah FKTP di wilayah BPJS Kesehatan Kantor Cabang Semarang. Setiap pelayanan kesehatan yang diperoleh secara otomatis akan ter-input dalam Aplikasi Pcare dan bila peserta melakukan kunjungan lebih dari tiga kali maka Aplikasi Pcare secara otomatis menolak. Untuk menghindari hal tersebut, petugas biasanya saat kunjungan awal akan menanyakan lama peserta domisili di FKTP tersebut bila lebih dari tiga bulan atau kemungkinan melebihi tiga kali kunjungan maka peserta akan disarankan untuk pindah FKTP. Kalau tidak maka peserta terpaksa harus membayar sebagai pasien umum atau peserta bisa memanfaatkan akses pelayanan kesehatan di FKTP terdaftar.

Sesuai hasil penelitian, kelima Puskemas menerapkan prosedur layanan penerapan prinsip portabilitas bagi peserta JKN luar wilayah domisili dalam memperoleh akses pelayanan kesehatan di Kota Semarang didasarkan pada Surat Edaran yang ada. Padahal Surat Edaran tersebut bukanlah peraturan teknis yang bersifat mengikat peserta JKN luar wilayah domisili Kota Semarang, Puskesmas sebagai FKTP, dan BPJS Kesehatan Kantor Cabang Semarang maka diperlukan peraturan teknis yang dapat mengikat berupa Keputusan Menteri. Hal ini dimaksudkan agar ada kepastian hukum bagi peserta JKN luar wilayah domisili, puskesmas sebagai FKTP, dan BPJS Kesehatan sendiri.

Isi surat edaran yang digunakan saat ini bila dianalisis dengan prinsip portabilitas yang menjadi dasar atau asas penyelenggaraan JKN oleh BPJS Kesehatan bertentangan. Prinsip portabilitas yang dijamin dalam Pasal 4 huruf $f$ UndangUndang SJSN dan Undang-Undang BPJS merupakan prinsip memberikan jaminan yang berkelanjutan meskipun peserta berpindah pekerjaan atau tempat tinggal dalam wilayah NKRI. Peserta JKN di luar wilayah domilisi juga harusnya tetap memperoleh jaminan tersebut dengan tidak dibatasi sementara dalam surat edaran tersebut dibatasi maksimal 3 (tiga) kali kunjungan dan harus mengurus pindah FKTP.

Karena prinsipnya peserta harus selalu terjamin atau terlindungi kapan dan dimanapun peserta berada selama berada di dalam yurisdiksi Indonesia. Jaminan ini dimaksudkan untuk memberikan jaminan yang berkelanjutan sampai peserta meninggal dunia. Peserta yang berpindah pekerjaan atau tempat tinggal harus tetap terlindungi. Tak terkecuali juga bagi peserta yang sedang bepergian, jaminan 
tersebut tetap berlaku. Karena ketika orang sakit, maka sakit adalah pencetus (triger) untuk mendapatkan hak atas jaminan kesehatan ${ }^{49}$.

Berdasarkan penjelasan di atas, penerapan prinsip portabilitas bagi peserta JKN di luar wilayah domisili dalam memperoleh akses pelayanan kesehatan di Kota Semarang ditinjau dari persyaratan, prosedur administratif, dan prosedur layanan terutama di kelima Puskesmas yang diteliti belum berjalan dengan baik. Perlu adanya peraturan teknis berupa Keputusan Menteri yang mengatur agar peraturan tersebut dapat mengikat baik peserta JKN luar wilayah domisili, Puskesmas sebagai FKTP, dan BPJS Kesehatan sebagai penyelenggara JKN. Keputusan Menteri ini juga dimaksudkan dapat memberikan kepastian hukum.

Hal tersebut tentu saja agar prinsip portabilitas yang merupakan salah satu prinsip penyelenggaraan program JKN sesuai dengan amanat Pasal 4 huruf $\mathrm{f}$ Undang-Undang SJSN dan Undang-Undang BPJS dapat diterapkan dengan baik.

3. Faktor-faktor yang mempengaruhi penerapan prinsip portabilitas bagi peserta JKN di luar wilayah domisili dalam memperoleh akses pelayanan kesehatan di Kota Semarang

Adapun faktor-faktor yang mempengaruhi penerapan prinsip portabilitas bagi peserta JKN di luar wilayah domisili dalam memperoleh akses pelayanan kesehatan di Kota Semarang antara lain:

a. Faktor yuridis

Penerapan prinsip portabilitas bagi peserta JKN di luar wilayah domisili dalam memperoleh akses pelayanan kesehatan di Kota Semarang, terutama di kelima Puskesmas yang diteliti didasari pada Surat Edaran BPJS Kesehatan Kantor Cabang Semarang Nomor 766/VI-01/0518 tentang Pelayanan Peserta Luar Wilayah di FKTP.

Permasalahannya sebagai surat edaran bukan merupakan peraturan teknis yang dapat mengikat sehingga diperlukan peraturan teknis barupa Keputusan Menteri yang memuat tentang persyaratan, prosedur administratif, dan prosedur layanan penerapan prinsip portabilitas bagi peserta JKN di luar wilayah domisili dalam memperoleh akses pelayanan kesehatan di Indonesia pada umumnya dan Kota Semarang pada khususnya. Keputusan Menteri tersebut juga dapat memberikan kepastian hukum bagi peserta JKN di luar wilayah domisili, Puskesmas sebagai FKTP, dan BPJS Kesehatan sebagai penyelenggara JKN.

Keputusan Menteri ini juga dimaksudkan sebagai peraturan teknis yang lebih spesifik dan rinci setelah di tuangkan secara umum dalam peraturan perundanganundangan yang menjadi mendasari pengaturan prinsip portabilitas bagi peserta JKN di luar wilayah domisili dalam memperoleh akses pelayanan kesehatan.

Menilik dalam Pasal 55 ayat (3) Peraturan Presiden Nomor 82 Tahun 2018 Tentang Jaminan Kesehatan bahwa, "Peserta yang berada di luar wilayah FKTP tempat Peserta terdaftar sebagaimana dimaksud pada ayat (2) huruf a dapat mengakses pelayanan rawat jalan tingkat pertama pada FKTP lain untuk paling banyak 3 (tiga) kali kunjungan dalam waktu paling lama 1 (satu) bulan di FKTP yang sama"50.

\footnotetext{
49 Hasbullah Thabrany, op.cit., hal. 155-156.

50Peraturan Presiden Nomor 82 Tahun 2018 tentang Jaminan Kesehatan diakses dari http://peraturan.go.id/common/dokumen/In/2018/ps82-2018.pdf pada tanggal 28 November 2018.
} 
Ketentuan ini sangat jelas batasannya namun sebagai perundang-undangan yang bersifat umum tidak perlu dijelaskan secara detail dalam peraturan tersebut. Hal ini dimaksudkan agar peraturan teknis yang bersifat spesifik diatur terpisah dalam Keputusan Menteri bukan berupa surat edaran semata. Bila demikian, penerapan prinsip portabilitas bagi peserta JKN di luar wilayah domisili dalam memperoleh akses pelayanan kesehatan di Kota Semarang semakin dengan mudah diterapkan.

b. Faktor sosial

Faktor sosial yang dimaksud adalah keadaan yang dipengaruhi oleh masyarakat sehingga peserta JKN di luar wilayah domisili tidak dapat dalam memperoleh akses pelayanan kesehatan di Kota Semarang berdasarkan prinsip portabilitas. Peserta sebagai sasaran dalam program JKN dengan tujuan terjaminnya kebutuhan kesehatan yang layak untuk mencapai derajat kesehatan setinggi-tingginya tentu sangat mempengaruhi keberhasilan program itu sendiri.

Faktor sosial yang mempengaruhi penerapan prinsip bagi peserta JKN di luar wilayah domisili dalam memperoleh akses pelayanan kesehatan di Kota Semarang sehingga peserta tidak memperolehnya adalah

1) Masih banyak peserta JKN luar wilayah domisili yang tidak menggunakan kartu JKNnya dalam memperoleh akses pelayanan kesehatan di FKTP termasuk Puskemas karena ketidaktahuan dan kurangnya informasi penerapan prinsip portabilitas sehingga memilih membayar biaya pelayanan kesehatan sebagai pasien umum ketimbang harus ribet.

2) Masih banyak peserta JKN luar wilayah domisili yang meskipun lama domisilinya lebih dari 3 (tiga) bulan atau kemungkinan melebihi batas maksimal kunjungan yaitu lebih dari tiga kali tetap tidak mau pindah FKTP dan bersikap acuh terhadap perubahan yang ada dan terkesan pasrah mengakibatkan peserta tidak memiliki kesadaran untuk memanfaatkan haknya. Hal ini tampak dari peserta JKN luar wilayah domisili di Kota Semarang yang tetap tidak mau pindah FKTP dengan berbagai alasan.

c. Faktor teknis

Faktor teknis dalam penerapan prinsip portabilitas bagi peserta JKN di luar wilayah domisili dalam memperoleh akses pelayanan kesehatan di Kota Semarang adalah

1) Petugas BPJS Kesehatan Kantor Cabang Semarang dalam upaya sosialisasi penerapan prinsip portabilitas bagi peserta JKN di luar wilayah domisili dalam memperoleh akses pelayanan kesehatan di Kota Semarang belum mencapai sebagian besar sasaran dan media sosialisasi yang digunakan masih kurang menarik. Akibatnya peserta JKN luar wilayah domisili masih belum tahu tentang penerapan prinsip portabilitas.

2) Perubahan data FKTP termasuk pindah FKTP dalam Aplikasi Pcare terbaca pada tanggal 1 (satu) pada bulan berikutnya. Hal ini menunjukkan bahwa perubahan data FKTP tidak serta merta langsung berubah atau bukan merupakan sistem online saat peserta melakukan perubahan namun harus menunggu perubahan pada bulan berikutnya.

3) Petugas puskesmas belum memahami pemanfataan aplikasi Mobile JKN sehingga penyampaian informasi pindah FKTP dengan aplikasi Mobile JKN yang 
diharapkan dapat sampai dengan tepat dan benar kepada peserta dalam penerapannya belum sesuai dengan yang diharapkan.

\section{KESIMPULAN}

1. Bentuk Pengaturan tentang penerapan prinsip portabilitas bagi peserta JKN di luar wilayah domisili dalam memperoleh akses pelayanan kesehatan di Kota Semarang sudah ada dalam UUD 1945, Undang-Undang SJSN, Undang-Undang Kesehatan, UndangUndang BPJS, Perpres Nomor 19 Tahun 2016 tentang Perubahan atas Perpres Nomor 12 Tahun 2013 tentang Jaminan Kesehatan, Perpres Nomor 82 Tahun 2018 tentang Jaminan Kesehatan, Permenkes Nomor 99 Tahun 2015 tentang Perubahan atas Permenkes Nomor 71 Tahun 2013 tentang Pelayanan Kesehatan pada Jaminan Kesehatan Nasional, dan Peraturan BPJS Kesehatan Nomor 1 Tahun 2014 tentang Penyelenggara Jaminan Kesehatan. Bentuk pengaturan dalam peraturan perundang-undangan di atas pada dasarnya bersifat umum sehingga diperlukan adanya peraturan teknis yang bersifat mengikat. Berdasarkan hasil penelitian, dalam penerapan prinsip portabilitas bagi peserta JKN di luar wilayah domisili dalam memperoleh akses pelayanan kesehatan di Kota Semarang didasarkan pada Surat Edaran BPJS Kesehatan Kantor Cabang Semarang Nomor 766/VI-01/0518 tentang Pelayanan Peserta Luar Wilayah di FKTP. Padahal surat edaran tersebut bukanlah peraturan teknis yang dapat bersifat mengikat sehingga diperlukan peraturan teknis yang bersifat mengikat dalam penerapannya berupa Keputusan Menteri. Isi surat edaran melampaui peraturan perundang-undangan sehingga batal demi hukum.

2. Penerapan prinsip portabilitas bagi peserta JKN di luar wilayah domisili dalam memperoleh akses pelayanan kesehatan di Kota Semarang terutama di kelima Puskesmas yang diteliti bila ditinjau dari persyaratan, prosedur administratif, dan prosedur layanan belum berjalan dengan baik. Perlu adanya peraturan teknis berupa Keputusan Menteri yang mengatur agar peraturan tersebut dapat mengikat baik peserta JKN luar wilayah domisili, Puskesmas sebagai FKTP, dan BPJS Kesehatan sebagai penyelenggara JKN. Keputusan Menteri ini juga dimaksudkan dapat memberikan kepastian hukum. Penerapan prinsip portabilitas bagi peserta JKN di luar wilayah domisili memperoleh akses pelayanan kesehatan di Kota Semarang sesuai dengan bentuk pengaturan yang ada seharusnya tidak boleh dibatasi karena pada dasarnya penerapan prinsip portabilitas terus berkelanjutan sehingga peserta berhak memperoleh jaminan kesehatan berupa hak akses pelayanan kesehatan dimanapun kapanpun di seluruh Indonesia termasuk di Kota Semarang. Hal ini juga menunjukkan bahwa dengan prinsip portabilitas, peserta JKN dapat memperoleh hak akses pelayanan kesehatan tanpa harus pindah FKTP karena program JKN berlaku nasional.

3. Faktor-faktor yang mempengaruhi penerapan prinsip portabilitas bagi peserta JKN di luar wilayah domisili dalam memperoleh akses pelayanan kesehatan di Kota Semarang terdapat 3 (tiga) faktor yaitu faktor yuridis, faktor sosial, dan faktor teknis. Faktor yuridis yang mempengaruhi dalam penelitian ini adalah perlu adanya peraturan teknis berupa Keputusan Menteri yang bersifat mengikat baik peserta JKN luar wilayah domisili, Puskesmas sebagai FKTP, dan BPJS Kesehatan sebagai penyelenggara JKN sehingga bukan berupa surat edaran yang hanya bersifat memberitahu dan tidak mengikat. Keputusan Menteri tersebut memuat persyaratan, prosedur administrasi, dan prosedur layanan penerapan prinsip portabilitas bagi peserta JKN di luar wilayah domisili dalam memperoleh akses pelayanan kesehatan di FKTP termasuk Puskesmas. Faktor sosial yang 
mempengaruhi adalah masih banyak peserta JKN luar wilayah domisili Kota Semarang yang tidak menggunakan kartu JKN karena ketidaktahuan dan kurangnya informasi terkait penerapan prinsip portabilitas memilih membayar biaya pelayanan sebagai pasien umum ketimbang harus ribet serta sikap acuh peserta terhadap perubahan kebijakan yang ada mengakibatkan peserta tidak memiliki kesabaran untuk memanfaatkan haknya. Faktor teknis yang mempengaruhi adalah upaya sosialisasi petugas BPJS Kesehatan Kantor Cabang Semarang belum mencapai sebagaian besar sasaran peserta JKN luar wilayah dan media yang digunakan belum menaik, perubahan data peserta termasuk data pindah FKTP yang terbaca bulan berikutnya mengakibatkan tidak langsung update sehingga peserta berpikir kembali untuk pindah FKTP, dan petugas Puskesmas yang masih belum memahami pemanfaatan Aplikasi Mobile JKN sehingga saat menyampikan kepada peserta tidak sesuai dengan yang diharapkan.

\section{SARAN}

Berdasarkan hasil penelitian dan pembahasan tersebut di atas, maka peneliti dapat menyarankan hal-hal sebagai berikut:

1. Bagi Kementrian Kesehatan

Perlu adanya peraturan teknis berupa Keputusan Menteri yang mengatur secara jelas persyaratan, prosedur administrasi, dan prosedur layanan termasuk pemanfaatan aplikasi Mobile JKN penerapan prinsip portabilitas bagi peserta JKN di luar wilayah domisili dalam memperoleh akses pelayanan kesehatan di Indonesia pada umumnya dan Kota Semarang khususnya. Keputusan Menteri ini dimaksudkan memberikan kepastian hukum dalam penerapan prinsip portabilitas bagi peserta JKN luar wilayah domisili, Puskesmas sebagai FKTP, dan BPJS Kesehatan sebagai penyelenggara JKN.

2. BPJS Kesehatan Kota Semarang

BPJS Kesehatan Kota Semarang perlu mengkaji kembali kebijakan dalam Surat Edaran BPJS Kesehatan Kantor Cabang Semarang Nomor 766/VI-01/0518 tentang Pelayanan Peserta Luar Wilayah di FKTP yang ditujukan kepada Pimpinan FKTP Wilayah Kerja BPJS Kesehatan Kantor Cabang Semarang terkait batasan maksimal tiga kali kunjungan bagi peserta JKN di luar wilayah domisili atau FKTP. Karena prinsip portabilitas bersifat tidak terbatas atau jaminan yang diberikan berkelanjutan dimanapun dan kapanpun. Sehingga isi surat edaran yang berlaku saat ini batal demi hukum karena bertentangan dengan peraturan perundang-undangan di atasnya. Saat ini, semua sistem penyelenggaraan BPJS Kesehatan sudah dikembangkan secara online dan ketika peserta memperoleh pelayanan kesehatan di luar wilayah domisili tentunya langsung ter-input ke aplikasi Pcare maka peserta tidak perlu pindah FKTP.

Selain itu, perlu penggalakan sosialisasi penerapan prinsip portabilitas dan pemanfaatan aplikasi Mobile JKN kepada petugas puskesmas juga peserta dengan datang langsung ke tempat yang memiliki banyak peserta luar wilayah domisili seperti di universitas/kampus, dan perkantoran dengan media promosi yang lebih menarik.

3. Bagi Puskesmas sebagai Fasilitas Kesehatan Tingkat Pertama

Puskemas sebagai partner kerja BPJS Kesehatan harusnya dapat memberikan informasi pindah FKTP kepada peserta secara jelas termasuk pemanfaatan aplikasi Mobile JKN yang memudahkan peserta untuk pindah FKTP juga kemudahan-kemudahan lain dalam aplikasi tersebut sehingga perlu dilakukan evaluasi. 
4. Bagi peserta JKN di luar wilayah domisili

Peserta JKN di luar wilayah domisili sebaiknya selalu update perubahan kebijakan dalam program JKN agar peserta dapat memperoleh akses pelayanan kesehatan sebagai haknya tanpa harus membayar biaya pelayanan kesehatan sebagai pasien umum.

\section{DAFTAR PUSTAKA}

Ali, Zainuddin, 2015, Metode Penelitian Hukum, Jakarta: Sinar Grafika

Anonim, "Kartu JKN-KIS Laku di Setiap Wilayah”, dalam “Info BPJS Kesehatan, Edisi 47 Tahun 2017, diakses dari https:/bpjskesehatan.go.id/bpjs/dmdocuments/bbc24a1f1e75dc915ca1ff55b9cc5199.pdf tanggal 4 April 2018.

Anonim, “Layanan Ditawarkan dalam Sistem Digital”, Kompas, Jakarta: 16 November 2017, diakses dari https://kompas.id/baca/humaniora/ilmu-pengetahuanteknologi/2017/11/16/layanan-ditawarkan-dalam-sistem-digital/. 11 April 2018.

Anonim, "Peraturan BPJS yang rumit", Kompas, 9 Maret 2017, diakses dari https://kompas.id/baca/opini/2017/03/09/surat-kepada-redaksi-83/. 11 April 2018.

Anonim, "Peserta Program JKN dan Fasilitas Kesehatan JKN", BPJS Kesehatan, Jakarta, diakses dari https://bpjs-kesehatan.go.id/bpjs/index.php/home tanggal 4 April 2018.

Anonim, "Warga Keluhkan Sulitnya Perpindahan Fasilitas Kesesehatan dari BPJS Kesehatan", Okezone, Yogyakarta: 18 Februari 2018, diakses dari https://economy.okezone.com/read/2018/02/18/320/1861036/warga-keluhkansulitnya-perpindahan-fasilitas-kesehatan-dari-bpjs-kesehatan. 11 April 2018.

Ashshofa, Burhan, 2004, Metode Penelitian Hukum, Cetakan Keempat, Jakarta: Rineka Cipta

Dewata, Mukti Fajar Nur dan Yulianto Achmad, 2010, Dualisme Penelitian Hukum Normatif \& Empiris, Yogyakarta: Pustaka Pelajar

Gunawan, Imam, 2016, Metode Penelitian Kualitatif: Teori dan Praktik, Jakarta: Bumi Aksara

Humas BPJS Kesehatan, "Kota Semarang Menuju Universal Health Coverage", BPJS Kesehatan, Jakarta, diakses dari https://bpjskesehatan.go.id/bpjs/index.php/post/read/2017/580/Kota-Semarang-MenujuUniversal-Health-Coverage tanggal 4 April 2018.

Kementerian Kesehatan Republik Indonesia, 2014, Buku Pegangan Sosialisasi Jaminan Kesehatan Nasional (JKN) Dalam Sistem Jaminan Sosial Nasional, Jakarta: Kemenkes $\mathrm{RI}$

Peraturan Badan Penyelenggara Jaminan Sosial Kesehatan Nomor 1 Tahun 2014 tentang Penyelenggara Jaminan Kesehatan diakses dari http://bpjskesehatan.go.id/bpjs/arsip/view/10 tanggal 17 April 2018.

Peraturan Menteri Kesehatan Nomor 28 Tahun 2014 tentang Pedoman Pelaksanaan Program Jaminan Kesehatan Nasional diakses dari http://peraturan.go.id/common/dokumen/bn/2014/bn874-2014.pdf pada tanggal 17 April 2018. 
Peraturan Menteri Kesehatan Nomor 71 Tahun 2013 tentang Pelayanan Kesehatan pada Jaminan Kesehatan Nasional diakses dari http://peraturan.go.id/common/dokumen/bn/2013/bn1400-2013.pdf tanggal 09 Agustus 2018.

Peraturan Menteri Kesehatan Nomor 75 Tahun 2014 tentang Pusat Kesehatan Masyarakat diakses dari http://peraturan.go.id/common/dokumen/bn/2014/bn1676-2014.pdf pada tanggal 23 Oktober 2018.

Peraturan Menteri Kesehatan Nomor 99 Tahun 2015 tentang Perubahan Atas Peraturan Menteri Kesehatan Nomor 71 Tahun 2013 tentang Pelayanan Kesehatan pada Jaminan Kesehatan Nasional diakses dari http://peraturan.go.id/common/dokumen/bn/2016/bn15-2016.pdf tanggal 28 November 2018.

Peraturan Pemerintah Nomor 101 Tahun 2012 Tentang Penerima Bantuan luran Jaminan Kesehatan diakses dari http://peraturan.go.id/common/dokumen/ln/2012/pp1012012 bt.pdf tanggal 26 Agustus 2018.

Peraturan Pemerintah Nomor 47 Tahun 2016 tentang Fasilitas Pelayanan Kesehatan diakses dari http://peraturan.go.id/common/dokumen/ln/2016/pp47-2016bt.pdf tanggal 23 Oktober 2018.

Peraturan Presiden Nomor 12 Tahun 2013 tentang Jaminan Kesehatan diakses dari http://peraturan.go.id/common/dokumen/In/2013/ps12-2013.pdf tanggal 17 April 2018.

Peraturan Presiden Nomor 19 Tahun 2016 tentang Perubahan Kedua atas Peraturan Presiden Nomor 12 Tahun 2013 tentang Jaminan Kesehatan diakses dari http://peraturan.go.id/common/dokumen/In/2016/ps19-2016.pdf tanggal 17 April 2018.

Peraturan Presiden Nomor 82 Tahun 2018 tentang Jaminan Kesehatan diakses dari http://peraturan.go.id/common/dokumen/In/2018/ps82-2018.pdf pada tanggal 28 November 2018.

Pohan, Imbalo S, 2003, Jaminan Mutu Pelayanan Kesehatan (Dasar-Dasar Pengertian), Jakarta: Kesaint Blanc

Putri, Asih Eka, 2014, Paham JKN Jaminan Kesehatan Nasional, Jakarta: Friedrich Ebert Stiftung (FES)

Sarwo, Yohanes Budi, 2012, Sistem Jaminan Sosial Kesehatan yang Berkeadilan dalam Negara Kesejahteraan di Indonesia, Semarang: Universitas Katolik Soegijapranata

Soekanto, Soerjono, 1986, Pengantar Penelitian Hukum, Cetakan 3, Jakarta: Penerbit Universitas Indonesia (UI-Press)

Surat Edaran BPJS Kesehatan Kantor Cabang Semarang Nomor 766/VI-01/0518 tentang Pelayanan Peserta Luar Wilayah di FKTP

Thabrany, Hasbullah, 2015, Jaminan Kesehatan Nasional, Edisi kedua, Jakarta: PT RajaGrafindo Persada

Undang-Undang Dasar Negara Republik Indonesia Tahun 1945 diakses dari http://jdih.pom.go.id/uud1945.pdf tanggal 01 November 2017. 
SOEPRA Jurnal Hukum Kesehatan

TERAKREDITASI RISTEKDIKTI Peringkat 4

ISSN:2548-818X (media online) Vol. 7 (1) Juni 2021

Undang-Undang Nomor 24 Tahun 2011 tentang Badan Penyelenggara Jaminan Sosial diakses dari http://bpjs-kesehatan.go.id/bpjs/index.php/unduh/index/1 pada tanggal 01 November 2017.

Undang-Undang Nomor 36 Tahun 2009 tentang Kesehatan diakses dari http://peraturan.go.id/common/dokumen/ln/2009/uu36-2009.pdf tanggal 07 April 2017.

Undang-Undang Nomor 40 Tahun 2004 tentang Sistem Jaminan Sosial Nasional diakses dari http://peraturan.go.id/common/dokumen/In/2004/uu40-2004.pdf tanggal 01 November 2017.

Waluyo, Bambang, 1996, Penelitian Hukum dalam Praktek, Edisi 1, Jakarta: Sinar Grafika

Widanti, Agnes, Endang Wahyati, Trihoni Nalesti Dewi, dan H. Hermawan Pancasiwi, 2015, Petunjuk Penulisan Usulan Penelitian Dan Tesis, Semarang: Unika Soegijapranata

Yustina, Endang Wahyati, 2015, "Hak atas Kesehatan dalam Program Jaminan Kesehatan Nasional dan Corporate Social Responsibility (CSR)", Kisi Hukum, Jurnal Ilmu Hukum Unika Soegijapranata, Vol.14, No.1 diakses dari http://journal.unika.ac.id/index.php/kh/article/view/461 tanggal 23 Maret 2018. 